\title{
Türk İşletme Gruplarında Ortak Yönetim Kurulu Üye Profili*
}

Tülay IILHAN NAS**

\author{
Merve ÖZDEN ÇAKA***
}

\begin{abstract}
$\ddot{O} Z$
Bu çalışmada, kurumsal yönetişim bağlamında Türk işletme gruplarında yaygın olarak görülen ortak yönetim kurulu üyeliklerinin mevcut ăg yapıları, incelenmeye çalışılmaktadır. Bu çerçevede, kasitll örnekleme yöntemi ile belirlenen 10 işletme grubunun ortak yönetim kurulu üyeliklerine dair ăg yapıları, 2011 ve 2014 ylllarına ait elde edilen ikincil verilerden yararlanılarak ortaya konulmuştur. Tüm ağlar dikkate alındığında, Türk işletme gruplarında ortak yönetim kurulu üyeliği bulunan en merkezi aktörlerin, genellikle ya aile üyeleri ya da uzun yillar şirkette çalışması sonucu artık aile üyelerinden biri gibi görülen iç üyeler olduklarl, otomotiv sektöründe ise bu üyelerin sektörde geniş deneyimlere sahip olan şirket CEO'larından oluştuğu görülmektedir.
\end{abstract}

Anahtar Kelimeler: Ortak Yönetim Kurulu Üyelikleri, Issletme Grupları, Türkiye Bağlamı. JEL Sinıflandırmast: M10; M19

\section{Shared Board Member Profile in Turkish Business Groups}

\begin{abstract}
In this study, the existing network structures of shared board memberships commonly seen in Turkish business groups are studied with regard to corporate governance. In this framework, the network structures of 10 business groups, determined by judgmental sampling, are shown by using secondary data. Taking into consideration all networks, the most central actors in Turkish business groups are either family members or internal members who are regarded as family members due to their long years of work in companies, while in automotive sector, those members are composed of CEO's with many years of experience.
\end{abstract}

Keywords: Shared Board Memberships, Business Groups, Turkey Context.

JEL Classification: M10; M19

\section{GİRIŞ}

Genel olarak gelişmekte olan ülke bağlamlarında özelde de Türkiye'de etkin kurumsal yönetişim mekanizmaları ile işletmelerin yönetim kurulu ve sahiplik yapılarının, gelişmiş ülkelerden farklı ve özellikli bir yapıya sahip olduğu bilinmektedir (İlhan-Nas, vd., 2018a: 174). Bu çalışmada, Türk işletme gruplarının bağlı kuruluşlarının yönetim kurullarında sıklıkla görülen, bağlı kuruluşları

\footnotetext{
* Bu çalışma, Karadeniz Teknik Üniversitesi, SBE, Yönetim ve Organizasyon ABD’nda 2016 tarihinde sunulan "İşletme Gruplarında Ortak Yönetim Kurulu Üye Profili” Başlıklı yüksek lisans tezinden üretilmiştir. Çalışmanın öncül bir formatı Sabancı Üniversitesi ev sahipliğinde düzenlenen 24. Ulusal Yönetim ve Organizasyon Kongresinde sunulmuş olup Kongre Bildiri Kitapçı̆̆ında yer almıştır.

** Prof. Dr., Karadeniz Teknik Üniversitesi, İ.İ.B.F. İşletme Bölümü, tulayilhan@ yahoo.com / tulayco@ktu.edu.tr ${ }^{* * *}$ Öğr. Grv., Gümüşhane Üniversitesi, Sosyal Bilimler MYO, Muhasebe ve Vergi Bölümü, merweozden@hotmail.com

${ }^{* * * *}$ Doç. Dr., Tarhan OKAN, Bandırma Onyedi Eylül Üniversitesi, Ömer Seyfettin Uygulamalı Bilimler Fakültesi, YBS Böl., tokan@bandirma.edu.tr 
yönetmede ve işletme gruplarının iç dinamiklerini anlamada kilit öneme sahip olan, ancak ilgili yazında gereken önemi görmeyen ortak yönetim kurulu üyeliklerinin irdelenmesi amaçlanmaktadır. Bu doğrultuda ortaya konulan iki araştırma sorusu çalışmayı yönlendirmektedir. Bu sorulardan ilki, "Türk aile işletme gruplarının kendi içlerinde oluşturdukları ortak yönetim kurulu üyelerinin kimlerden oluştuğu?" ile ilgilidir. Aile sahipli işletme grupları geç endüstrileşmiş ekonomilerde baskın bir örgütsel form olarak görülmektedir (Amsden ve Hikino, 1994; Buğra, 1995; Guillen, 2000; Selekler-Gökşen ve Üsdiken, 2001). Türkiye yasal düzenlemeler, muhasebe standartları ve hissedarların korunmas1 gibi alanlarda zayıf kurumların, piramit sahipli işletme gruplarının ve aile temelli sahiplik yoğunlaşmasının hâkim olduğu bir kurumsal yönetişim çevresine sahiptir (Yurtoğlu, 2003: 3; Demirağ ve Serter, 2003: 48). Selekler-Gökşen ve Karataş (2008: 138) Türkiye'de dışsal kurumsal yönetişim mekanizmalarının oldukça zayıf olduğunu belirtmektedirler. Bu anlamda Yurtoğlu'nun (2003) içsel sistem olarak sınıflandırdığı Türkiye' de aile işletme grupları, firma kontrolü için dışsal yönetişim mekanizması olarak pazara güvenmemektedirler (Selekler-Goksen ve Karatas, 2008: 138). Firma kontrolü için aktif pazarların söz konusu olmadığı bu çevresel bağlamlarda ortaya çıkan kurumsal yönetişim biçimi sahiplik yoğunlaşması ve yönetim kurulları şeklinde olmaktadır (Yurtoğlu, 2003; Claessens vd., 1998; Shleifer ve Vishny,1997). Türkiye bağlamı özelinde, kurucu aile üyeleri hem firmayı yönetmekte hem de firma üzerinde daha fazla kontrolü elinde tutmak istemektedirler (Buğra, 2007). Bu amaçla işletme sahipleri, genellikle piramit sahiplik yapıları, aile üyelerinin veya aileden olarak kabul edilen (aile ile uzun süreli ilişkileri bulunan) profesyonel yöneticilerin ağırlıklı olduğu yönetim kurulları, çoklu yönetim kurulu üyelikleri gibi mekanizmalar aracılığıyla işletme gruplarını kontrol etmeye çalışmaktadırlar.

$\mathrm{Bu}$ mekanizmalardan ortak yönetim kurulu üyelikleri, gelişmiş ülkelerde bilgi paylaşımı ve belirsizlikle başa çıkma amacı ile oluşturulurken (Maman, 1999; Gulati ve Westphal, 1999) Türkiye'de ise, yukarıda bahsedilen sebeplerden dolayı, sahipliği elinde bulunduran aileler tarafından işletme grubunun bağlı şirketlerini (affiliated) denetlemek ve bu şirketler arasında koordinasyonu sağlamak için kullanılmaktadır (Ataay, 2008). Dikey kenetlenmeler, işletme grubunun bağlı şirketlerini kontrol etmesini mümkün k1larken, yatay kenetlenmeler ise bağlı şirketler arasındaki koordinasyonu sağlamak için oluşturulmaktadır (Mizruchi, 1996). Bu çalışmada da, A $\breve{g}$ Kuramı çerçevesinde, Türk aile işletme gruplarında ortak yönetim kurulu üyelerinin özellikleri ve ağ ilişkileri ortaya konulmaya çalışılmaktadır.

Türk iş sisteminin bahsedilen ayrıcalıklı yapısı çerçevesinde düşünüldügünde, Yeni Türk Ticaret Kanunun (YTTK) yürürlüğe girdiği 2012 yll, kırllma noktası olarak alındı̆̆ında, bu yllın öncesi ve sonrasinda ortak yönetim kurulu üye profilinde herhangi bir değişimin yaşanıp yaşanmadiğı? çalışmanın zeminini oluşturan ikinci önemli araştırma sorusu olarak gündeme gelmektedir. Böyle bir soru, YTTK ile gelen düzenlemelerin ortak yönetim kurulları üzerinde yarattığı etkilerin ayrıca ele alınmasını gerektirmektedir. Her ne kadar YTTK ile 
yönetim kurulunun bağımsızlaştırılması ve azınlıkların haklarını korumaya yönelik geliştirilen düzenlemelerin içeriği ve işlerliği çeşitli açılardan sorgulanan (örneğin, Üsdiken ve Öktem, 2008; Arıkboğa ve Menteş, 2012; İlhan-Nas vd., 2018; İlhanNas ve Kalaycıoğlu, 2016; İlhan-Nas ve Çarkçı, 2015) bir konu olsa da söz konusu yasal çerçevenin ortak yönetim kurulları düzeyinde ne tür etkiler yarattığı tam anlamı ile bilinmemektedir. Bu kapsamda düşünüldügünde, mevcut çalışmanın Türk aile işletme gruplarında ortak yönetim kurulu üye profilini ortaya koymanın yanı sıra Türkiye bağlamında işletme grubu düzeyinde YTTK'nın etkisini görme fırsatı da sunarak yazına ve konu ile ilgilenen araştırmacılara katkı sağlaması beklenmektedir.

Çalışmanın bundan sonraki bölümünde ilgili yazın ışığında oluşturulan kavramsal çerçevesi sunulmaktadır. Üçüncü bölümde araştırma tasarımı ve analiz bulguları verilmektedir. Çalışma sonuç ve tartışma bölümüyle son bulmaktadır.

\section{KAVRAMSAL ÇERÇEVE}

\section{A. İșletme Grupları}

Geç gelişen ülkelerde baskın bir örgütsel form olarak görülen işletme gruplarının (Özkara vd., 2008: 59) ilgili yazında kabul gören ortak bir tanımını yapmak mümkün görünmemektedir (Dirlik, (2014a: 11). Ülkelerin kurumsal bağlamları ve iş sistemleri bu örgütsel formun yapılarını farklılaştırmaktadır. Granovetter (2005: 429) işletme gruplarını yasal olarak birbirinden bağımsız olmakla birlikte biçimsel ya da biçimsel olmayan bağlarla birbiriyle ilişkili şirketler topluluğu olarak tanımlamaktadır. Collin (1998: 719) ise işletme gruplarını örgütler üstü bir yap1 olarak niteleyerek sahiplik yapıs1 ve sermaye mülkiyeti mekanizmasıyla yasal olarak birbirinden bağımsız firmaların birlikteliği olmasına vurgu yapmaktadır. Maman (2002: 739) da işletme grubu tanımında, hukuksal biçimde birbirinden bağımsız, hisse senedi gibi resmi ya da aile bağları gibi gayri resmi bağlarla oluşturulmuş bir örgütsel yapıya dikkat çekmektedir. İşletme grupları çok farklı sektörlerde faaliyet gösteren ve çoğunlukla bir aile ile bağlantılı iş örgütlenmeleridir (Khanna ve Rivkin, 2001: 47). Bu örgütsel formda yasal olarak birbirinden bağımsız olan bağlı kuruluşların birbirleriyle işbirliği halinde olmalarının temel nedenlerinden biri olarak da ortak ekonomik refahlarını arttırmak görülmektedir (Çolpan ve Hikino, 2010: 17).

İşletme grupları her ülkede farklı bir isimle anılmakta ve örgütsel yapıları da ortaya çıktıkları ülke ya da bölgelere göre değişmektedir (Özkara ve diğerleri, 2008: 60). Buna karşın söz konusu örgütsel formlara atfedilen ana tanımlayıcı özellikler, Türkiye'deki aile holdingleri ile, Japon "zabiatsu/keiretsu", Güney Koreli "chaebol", Tayvanlı "guanxi qiye", Çinli "qiye jituan", Latin Amerika ve İspanyadaki "grupos", Hindistanl1 "business houses", Pakistanl1 ""twenty two families" gibi formlar ortak bir kavramsal yapı çatısı altında ele alınmaktadırlar (Karaevli, 2008: 88; Özkara vd., 2008: 60; Dirlik, 2014a: 10). Bu çalışmada söz konusu örgütlerden bahsederken "işletme grubu" adının kullanılması tercih edilmiştir.

Türkiye bağlamında yapılan işletme grubu çalışmaları göz önünde bulundurulduğunda bu örgüt tipinin üç ortak tema etrafında oluştuğu çıkarımında 
bulunulabilmektedir. İlk tema işletme gruplarının çeşitlenme eğilimlerinin çok yüksek olduğu ve çeşitlenmenin ilişkisiz bir nitelik taşıdığıdır. İkinci tema işletme gruplarının ana holding denen bir çatıdan oluştuğu ve kendisine bağlı firmaların yasal olarak birbirinden ayrı varlıklar olup grubun bir merkezden yönetildiğidir. Üçüncü tema ise firmaların aile şirketi halini korur olmaları şeklinde özetlenebilmektedir.

İşletme grupları varlıklarının sürekliliğini sağlayabilmek, firma faaliyetlerini yönetip kontrol etmek, diğer işletme gruplarından farklı ve ayırt edici bir kimliğe bürünebilmek gibi çeşitli nedenlerle başlangıç aşamasında olmasa bile şirketlerin faaliyetlerinin büyümesiyle birlikte ilerleyen dönemlerde bir takım çeşitli düzenlemelere, ilkelere, yasalara ihtiyaç duyabilmektedirler. Türkiye'de kullanılan bu düzenlemelerden biri de kurumsal yönetişim mekanizmalarıdır.

\section{B. Türk İşletme Gruplarında Ortak Yönetim Kurulu Üyelikleri}

Kaynak Bağımlılığı Yaklaşımına göre, ortak yönetim kurulu üyelikleri firma için değerli kaynakların belirsizlik ve kıtlık seviyesi ile ilişkilendirilerek ele alınmaktadır. Bununla birlikte, Türk işletme gruplarında oluşturulan ortak yönetim kurulu üyeliklerinin temel motivasyonunun önemli kaynakların tedarikinden ziyade, işletme grubu düzeyinde koordinasyon ve kontrolü sağlamak olduğu öne sürülmektedir (Ataay, 2008). Bu noktada, sağlanan doğrudan ve dolaylı yönetim kurulu üyeliklerinin yatay ve dikey koordinasyonun faydalarını kazandıracağı düşünülmektedir (Scott, 2000: 7). Ortak yönetim kurulu üyeliklerinin işletme uygulamaları hakkında bilgi aktarımını kolaylaştıracağı, tepe yönetimin dayanışmasını sağlayacağ 1 , şirketler arası işbirliği sağlayıcı bir mekanizma görevi göreceği, yöneticilere bireysel kariyer firsatları sunacağı, bağımlılıkları azaltacağı, denetim ve gözetim aracı görevi göreceği, şirketin dış çevrelerde meşruiyetini sağlayacağı ve firsatçı bazı davranışları engelleyebileceği de ifade edilmektedir (Baycan ve Semerciöz, 2013; Barringer ve Harrison, 2000).

Türkiye bağlamına bakıldığında işletme gruplarının yönetim kurullarının daha çok aile üyelerinden oluştuğu, bu kurullarda dışarıdan üyelere çok sicak bakılmadığı, diş üyelere güvenilmediği için hayati önem taşıyan bilgilerin onlardan gizli tutulduğu ve bu sayede de yönetim kurulunda aile üyesi dışında yöneticilere yer verilse bile bu üyelerin bilgi eksikliklerinden ve yetersiz sosyal sermayeden dolayı gerekli çalışmaları gerçekleştiremedikleri görülmektedir (Buğra ve Üsdiken, 1995; Buğra, 2013). Yine dış çevreye olan bu güvensizlikten dolayı şirkette yer alan yöneticileri sürekli olarak denetleme isteği, maliyetlerin artmasına neden olmakta ve şirket sahipleri de hem bu maliyetleri en aza indirmek hem güvenilirliği, kontrolü ve koordinasyonu sağlamak için kendilerine bağlı olan işletme gruplarının yönetim kurullarına ya aile üyelerinden birini ya da şirkette uzun yıllar çalışması sonucu hem güven hem de tecrübe kazanarak emekli olmuş kişileri getirerek bu kontrolü sağlamak isteme eğiliminde oldukları bilinmektedir (Buğra ve Üsdiken, 1995; Ataay, 2008; Buğra, 2013). Üsdiken ve Öktem (2008: 61 ve 67) çalışmalarında, Türkiye'deki aile holdinglerine bağlı işletmelerin yönetim kurullarının yaklaşık olarak \%70'e varan bir çoğunluğunun, aile fertleri $(\% 19,3)$, "holding veya grubun diğer işletmelerin yöneticileri" $(\% 48,8)$ ve "holdingden 
emekli olanlar" $(\% 5,4)$ gibi "grubun içinden ama şirketin dişından" üyelerden oluştuğunu ortaya koymuşlardır. Araştırmacılar, kurul kompozisyonuna dair bu durumun, işletme gruplarının merkeziyetçiliğinin ve bağlı kuruluşları üzerinde kurdukları merkezi denetimin bir sonucu olarak yorumlamışlardır (Üsdiken ve Öktem, 2008: 67). Üsdiken ve Öktem (2008)'in çalışmasına koşut olarak, Koçer (2006) tarafından elde edilen bulgular da yönetim kurullarının \% 79.3'ünün aile bireylerinden ve gruba bağl1 profesyonel yöneticilerden oluştuğunu ortaya koymaktadır. Ataay (2008) İMKB 100 endeksinde yer alan şirketleri incelediği çalışmasında ise profesyonel yöneticilerin aile üyelerine kıyasla daha yoğun ortak yönetim kurulu üyelikleri olduğunu ileri sürmektedir. Şenalp ve Öztürk (2014) de 2004-2012 yılları arasında ISO 500 şirketleri örneklemiyle gerçekleştirdikleri çalışmalarında, aileden olan ortak yönetim kurulu üye sayısının yıllar itibariyle azaldığını ve profesyonellerden oluşan ortak yönetim kurulu üye sayısının arttığını ortaya koymaktadırlar. İlgili yazındaki mevcut çalışmalar çerçevesinde, Türk işletme gruplarında ortak yönetim kurulu üyelerinin aileden ya da holding veya bağlı kuruluşlarda çalışan aileye yakın profesyonel yöneticilerden oluşması beklenmektedir. Bu çerçevede aşağıdaki önerme ortaya konulabilir.

Önerme 1: Türk işletme gruplarında ortak yönetim kurulu üyeleri, kurucu/sahip aile bireylerinden ya da holding veya bağlı kuruluşlarda çalışan aileye yakın profesyonel yöneticilerden oluşmaktadır.

\section{ARAŞTIRMA TASARIMI}

\section{A. Araştırmanın Örneklemi ve Veri Seti}

Türk aile işletme gruplarının ortak yönetim kurulu üye profillerini ortaya koymayı amaçlayan bu çalışmanın evrenini oluşturan holdinglerin kesin bir listesinin elde etmenin (Buğra, 2007: 255; Dirlik, 2014a: 11; Koca, 2015: 99-100) ve mevcut holdinglerin bilgilerine ulaşmanın oldukça zor olduğu bilinmektedir (Buğra, 2007: 255). Belirtilen bu kısıt çerçevesinde, listelenen holdinglerin çalışma kapsamında elde edilmek istenen bilgilerine ulaşılabilme kolaylı̆̆ 1 da dikkate alınarak, evrenin belirlenmesinde; Çolpan ve Hikino (2008) tarafından yapılan çalışmada yer alan "Türkiye'nin en büyük 50 iktisadi aktörü" listesi ve KHU-KPMG-T-DEIK-VCC (2011) tarafindan yayımlanan araştırmada yer alan "En büyük 19 Türk finansal olmayan çokuluslu şirket" listesi referans alınmıştır. $\mathrm{Bu}$ iki çalışmanın tüm firmaları birleştirildiğinde Türkiye'de faaliyet gösteren 63 işletme grubu elde edilmektedir.

Belirlenen ana evren içerisinden örneklem seçmek üzere, tesadüfi ve sistematik hataları önlemek ve çalışmanın amacı çerçevesinde daha anlamlı sonuçlar üretebilmek amacı ile kasitlı örnekleme yöntemi tercih edilmiştir (İlhan, 2005: 97). Bu bağlamda çalışmanın örneklemini, en az 3 farklı sektörde ${ }^{1}$ faaliyet gösteren, bünyesindeki bağlı şirketlerin en az üçü halka açık olan, bağl1 şirketlerinden en az biri ISO 5002014 yılı firma siralamasında yer alan 10 holdingden ve bu holdinglere bağlı olarak faaliyet gösteren 61 adet bağl1 kuruluştan oluşturmaktadır. Bu noktada, 2012 yılında YTTK'da yaşanan değişimin yarattı̆̆ 1

\footnotetext{
${ }^{1}$ Endüstri sınıflandırması SIC kodlarına (https://www.osha.gov/pls/imis/sicsearch.html) göre gerçekleştirilmiştir.
} 
kırılma noktası da dikkate alarak, çalışmada 2011 ve 2014 yıllarına ait ikincil veri kullanılmıştır.

Çalışmada değişken olarak ele alınan ortak yönetim kurulu üyeliği, firmada ortak yönetim kurulu üyesi olarak görev yapan kişilerin toplam sayısı olarak tanımlanmaktadır. Ayrıca ortak üyeler; "aileden ortak yönetim kurulu üyesi", "bağımsız ortak yönetim kurulu üyesi", "profesyonel ortak yönetim kurulu üyesi" olarak ayrı ayrı irdelenmiştir. Ortak yönetim kurulu üyeliklerine dair bu bilgiler, şirketlerin yıllık faaliyet raporları, Kamuyu Aydınlatma Platformunda (KAP) yer alan şirket bilgi sayfaları ve zaman zaman yönetim kurulu üyelerinin özgeçmişleri incelenerek elde edilmiştir.

\section{B. Analiz Yöntemi}

Türk işletme gruplarında ortak yönetim kurulu ağlarını ve üye profillerini ortaya koyabilmek için uygulanan sosyal ağ analizi için UCINET programı kullanılmıştır. Örneklem kapsamına alınan holdingler için hangi işletmelerin hangi işletmelerle, hangi yönetim kurulu üyelerinin hangi işletmelerin yönetim kurulu üyeleriyle ortak çalışma yürüttükleri tespit edildikten sonra, elde edilen ağırlıklandırılmış veriler UCINET (Borgatti ve diğerleri, 2002) programı kapsamında oluşturulan sıklık tablolarına aktarılmıştır. Elde edilen sosyal ağ çerçevesinde oluşan düğüm noktaları arasındaki ilişkilerin daha detaylı görünebilmesi için NETDRAW ve UCINET programları kullanılarak sosyal ağlar grafiksel olarak gösterilmiştir. Bu aşamada örneklemde yer alan şirketlerin 20112014 yıllarındaki merkezilik ve arasındalık verilerine bakılarak İşletme gruplarının ve bu işletmelerde görev yapan yönetim kurulu üyelerinin yıllar içerisindeki üye profili karşılaştırılarak işletme gruplarının yönetim kurulu üyelerinin kimlerden oluştuğu ve söz konusu üyelerin merkezilik ve arasındalık rolleri ortaya konulmuştur.

\section{Analiz Süreci ve Bulgular}

Çalışmanın amacı çerçevesinde uygulanan sosyal ağ analizi sürecinde ortak yönetim kurulu üyelerine dair ağ yapıları elde edilirken, firma ve birey düzeyinde olmak üzere iki farklı bakış açısı benimsenmiştir. Bu çerçevede;

1- Firma düzeyinde; ortak yönetim kurulu üyesi bulunan "işletme grupları ve bağl1 kuruluşlar" düzeyinde tanımlanan sosyal ağ matrisi, kendi aralarında ortak yönetim kurulu üyesine sahip olan firmalar arasındaki sosyal ağ1,

2- Birey düzeyinde; ortak yönetim kurulu üyeliği bulunan "yönetim kurulu üyeleri" düzeyinde tanımlanan ağ matrisi ise farklı firmaların kurullarında bir arada görev yapmakta olan bireyler arasındaki sosyal ağ temsil etmektedir.

Analiz sürecinde, tanımlanan ağ matrisleri sosyal ağ analizinde sıklıkla kullanılan derece merkezilik ve arasındalık ölçütleri ele alınarak değerlendirilmiştir. Bu kapsamda; firma düzeyinde tanımlanan ortak yönetim kurulu üyeliklerine ilişkin 2011 ve 2014 yılına ait veriler ağ analizi programına girildiğinde işletme grupları ve bağlı kuruluşları bazında her 2 yıl için de 61 x 61 ' lık bir veri matrisi elde edilmiştir. Birey düzeyinde ise yönetim kurullarında bulunan 
üyelerin kendilerinin veya sayılarının her yıl değişebilmesi sebebiyle 2011 yılı için 318 x 318'lik 2014 yılı için ise 334x334'lük veri matrisleri elde edilmiştir.

Tanımlanan bu ağ matrisleri, sosyal ă̆ haritalarının oluşturulmasını sağlamıştır. Araştırmada hem kendi aralarında ortak yönetim kurulu üyeliği bulunan "işletme grupları ile bağlı kuruluşlarının" hem de ortak yönetim kurulu üyeliği bulunan yönetim kurulu üyelerinin bulgularına yer verilmektedir. Analiz esnasında aynı zamanda derece merkezilik değerinin yüzde olarak ifade edilen azami muhtemel derece merkeziliğe bölümü ile elde edilen normalize edilmiş derece merkeziliği (normalized degree centrality) ölçümü de yapılarak bu sayede ağda meydana gelebilecek maksimum ilişki seviyesi ile güncel durum arasında bir mukayese yapılabilmesinin sağlanması amaçlanmıştır. Firma düzeyinde ortak yönetim kurulu üyesi bulunan "işletme grupları ve bağlı kuruluşlar" ve birey düzeyinde ortak yönetim kurulu üyeliği bulunan "yönetim kurulu üyeleri” için uygulanan sosyal ağ analizi sonuçları aşağıda ayrıntılı olarak sunulmaktadır.

Firma Düzeyinde Ortak Yönetim Kurulu Üyesi Bulunan "İşletme Grupları ve Bağlı Kuruluşlar" İçin Sosyal Ağ Analizi -Merkezilik- Sonuçları

Ortak yönetim kurulu üyeliği bulunan işletme grupları ile bağlı kuruluşlarına ait merkezilik puanları ve merkezilik puanlarına dair tanımlayıcı istatistikler Tablo 1'de sunulmaktadir.

Tablo 1. Ortak Yönetim Kurulu Üyeliği Bulunan "İşletme Grupları ve Bağlı Kuruluşların” Merkezilik Puanları ve Merkezilik Puanlarına Dair Tanımlayıcı İstatistikler

\begin{tabular}{|c|c|c|c|c|c|}
\hline \multirow{2}{*}{$\begin{array}{l}\text { Issletme } \\
\text { Gruplart }\end{array}$} & \multirow{2}{*}{ Bağlı Kuruluşlar } & \multicolumn{2}{|c|}{ Derece } & \multicolumn{2}{|c|}{ Normlu Derece } \\
\hline & & 2011 & 2014 & 2011 & 2014 \\
\hline Koç Holding & 1.Tüpraş Türkiye Petrol R. A.Ş. & 34.000 & 30.000 & 7.083 & 7.143 \\
\hline Koç Holding & 2.Arçelik A.Ş & 32.000 & 27.000 & 6.667 & 6.429 \\
\hline Koç Holding & 3.Aygaz A.Ş. & 23.000 & 18.000 & 4.792 & 4.286 \\
\hline Koç Holding & 4.Tat Gıda Sanayi A.Ş. & 21.000 & 19.000 & 4.375 & 4.524 \\
\hline Yaşar Holding & 5.Viking Kağıt ve Selüloz A.Ş. & 21.000 & 22.000 & 4.375 & 5.238 \\
\hline Anadolu & 6.Anadolu Efes Biracılik ve Malt & 21.000 & 16.000 & 4.375 & 3.810 \\
\hline Holding & Sanayi A.Ş. & & & & \\
\hline Yaşar Holding & 7.DYO Boya Fabrikaları San.T.A.Ş. & 19.000 & 20.000 & 3.958 & 4.762 \\
\hline Yaşar Holding & 8.Pınar Su Sanayi ve T.A.Ş. & 18.000 & 20.000 & 3.750 & 4.762 \\
\hline Koç Holding & 9.TOFAŞ Türk Otomobil Fab. A.Ş. & 18.000 & 20.000 & 3.750 & 4.762 \\
\hline Yaşar Holding & 10.Pınar Süt Mamülleri Sanayi A.Ş. & 18.000 & 19.000 & 3.750 & 4.524 \\
\hline Koç Holding & 11.Ford Otomotiv Sanayi A.Ş. & 17.000 & 15.000 & 3.542 & 3.571 \\
\hline Yaşar Holding & 12.Altın Yunus Çeşme Turistik T.A.Ş. & 17.000 & 16.000 & 3.542 & 3.810 \\
\hline Yaşar Holding & 13.Pınar Entegre Et ve Un Sanayi A.Ş. & 16.000 & 23.000 & 3.333 & 5.576 \\
\hline $\begin{array}{l}\text { Anadolu } \\
\text { Holding }\end{array}$ & 14. Yazıcılar Holding A.Ş. & 15.000 & --- & 3.125 & --- \\
\hline $\begin{array}{l}\text { Anadolu } \\
\text { Holding }\end{array}$ & $\begin{array}{l}\text { 15.Adel Kalemcilik Ticaret ve Sanayi } \\
\text { A.Ş }\end{array}$ & 15.000 & 18.000 & 3.125 & 4.286 \\
\hline Koç Holding & 16.Türk Traktör ve Ziraat M. A.Ş. & 14.000 & 14.000 & 2.917 & 3.333 \\
\hline Doğan Holding & 17.Doğan Şirketler Grubu H. A.Ş. & 14.000 & 11.000 & 2.917 & 2.619 \\
\hline Koç Holding & 18.Yap1 ve Kredi Bankası A.Ş. & 14.000 & 14.000 & 2.917 & 3.333 \\
\hline $\begin{array}{l}\text { Anadolu } \\
\text { Holding }\end{array}$ & $\begin{array}{l}\text { 19.Anadolu Isuzu Otomotiv } \\
\text { Sanayi.Tic. A.Ş. }\end{array}$ & 13.000 & 17.000 & 2.708 & 4.048 \\
\hline Doğan Holding & 20.Ditaş Doğan YedekParça İ. T. A.Ş. & 13.000 & --- & 2.708 & --- \\
\hline Doğan Holding & 21.Hürriyet Gazetecilik ve Matb. A.Ş. & 12.000 & --- & 2.500 & --- \\
\hline Doğan Holding & 22.Doğan Gazetecilik A.Ş. & 12.000 & --- & 2.500 & --- \\
\hline Koç Holding & 23.Otokar A.Ş. & 12.000 & --- & 2.500 & --- \\
\hline $\begin{array}{l}\text { Anadolu } \\
\text { Holding }\end{array}$ & 24.Coca-Cola İçecek A.Ş. & 12.000 & 15.000 & 2.500 & 3.571 \\
\hline
\end{tabular}


Tülay İlhan Nas \& Merve Özden Çaka \& Tarhan Okan / Türk Işsletme Gruplarında Ortak Yönetim Kurulu Üye Profili

\begin{tabular}{|c|c|c|c|c|c|}
\hline $\begin{array}{r}\text { Eczacıbassl } \\
\text { Holding }\end{array}$ & $\begin{array}{l}\text { 25.Eczacıbaşı Yatırım Holding } \\
\text { Ortalığı A.Ş }\end{array}$ & 11.000 & 12.000 & 2.292 & 2.857 \\
\hline Doğan Holding & 26.Çelik Halat ve Tel Sanayii A.Ş. & 11.000 & 10.000 & 2.292 & 2.381 \\
\hline $\begin{array}{r}\text { Eczacıbaşı } \\
\text { Holding }\end{array}$ & 27.Eczacıbaşı İlaç Sanayi ve TİC. A.Ş & 11.000 & --- & 2.292 & --- \\
\hline $\begin{array}{l}\text { Eczacıbaşı } \\
\text { Holding }\end{array}$ & 28.Eczacıbaişı Yatırım Ortaklığı A.Ş. & 11.000 & 12.000 & 2.292 & 2.857 \\
\hline Oyak Holding & 29. Bolu Çimento Sanayii A.Ş. & --- & 11.000 & --- & 2.619 \\
\hline Oyak Holding & 30. Mardin Çimento Ve San. Tic. A.Ş. & --- & 10.000 & --- & 2.381 \\
\hline \multirow{11}{*}{ Istatistikler } & Ortalama & 10.328 & 9.803 & 2.152 & 2.334 \\
\hline & Std Sap. & 7.348 & 6.885 & 1.531 & 1.639 \\
\hline & Toplam & 630.000 & 598.000 & 131.250 & 142.381 \\
\hline & Varyans & 53.991 & 47.404 & 2.343 & 2.687 \\
\hline & SSQ & $\begin{array}{c}9.800 .0 \\
00\end{array}$ & $\begin{array}{c}8.754 .0 \\
00\end{array}$ & 425.347 & 496.258 \\
\hline & MCSSQ & $\begin{array}{c}3.293 .4 \\
43\end{array}$ & $\begin{array}{c}2.891 .6 \\
39\end{array}$ & 142.945 & 163.925 \\
\hline & Öklid Normu & 98.995 & 93.563 & 20.624 & 22.277 \\
\hline & Minimum & 0.000 & 1.000 & 0.000 & 0.238 \\
\hline & Maximum & 34.000 & 30.000 & 7.083 & 7.143 \\
\hline & Ă̆ Merkezciliği (2011): \%5.10 & & & & \\
\hline & Ağ Merkezciliği (2014): \%4.97 & & & & \\
\hline
\end{tabular}

İşletme grupları ve bağlı kuruluşlara dair ağ Analizi merkezilik faktörü açısından incelendiğinde (Tablo 1) 2011 yılında örneklemde yer alan 10 İşletme Grubundan 5'inin ve bu işletme gruplarına bağlı 61 işletmeden 28'inin 2014 yılında ise 10 İşletme Grubundan 6'sının ve bu işletme gruplarına bağlı 61 işletmeden 24'ünün merkezilik açısından anlamlı sonuçlar içerdiği görülmektedir

${ }^{2}$. Tabloya ilişkin önemli bulgu 2014 yılına ait toplam merkezilik skorunun $(\mathrm{MD}=598.000) 2011$ yılına $(\mathrm{MD}=630.000)$ kıyasla belirgin bir şekilde azalış göstermesidir.

İşletme grupları ve bağlı kuruluşlar arasındaki ilişkiler ile ilgili bir fikir vermesi açısından, 2014 yılına ait ortak yönetim kurulu üyeliği bulunan "işletme grupları ve bağlı kuruluşların" ağ analizi- merkezilik sonuç diagramları ise Şekil 1'de sunulmaktadır ${ }^{3} .2014$ yılında örneklemde yer alan işletme grupları içerisinde Koç Holding bünyesinde yer alan işletmelerin daha büyük sembollerle ağda var oldukları görülmektedir. Koç Holdingi sırasıyla Yaşar Holding bünyesindeki işletmelerin takip ettiği, Sabanc1 Holding, Doğan Holding, Oyak Holding ve Anadolu Holdinge bağlı olan bazı işletmelerinde büyük sembollerle gösterildiği göze çarpmaktadır. Şişecam Holdingden Zorlu Holding, Vestel Holding ve Alarko Holding doğru gidildiğinde ise merkeziliğin derecesinin düşerek sembollerin daha da küçüldüğü gözlemlenmektedir.

\footnotetext{
2 İlgili tablolarda sadece merkezilik açısından anlamlı sonuçlar içeren bağlı kuruluşlar sunulmuștur.

${ }^{3}$ Ağ analizleri 2011 ve 2014 yılları için ayrı ayrı gerçekleştirilmiştir. Derginin sayfa sınırlaması nedeniyle burada sadece 2014 yılına ait ağ diyagramları sunulmaktadır. Arzu edildiği takdirde hem 2011 hem de 2014 yılına ait tüm detaylı analiz sonuçları ve ağ yapıları yazarlardan temin edilebilir.
} 

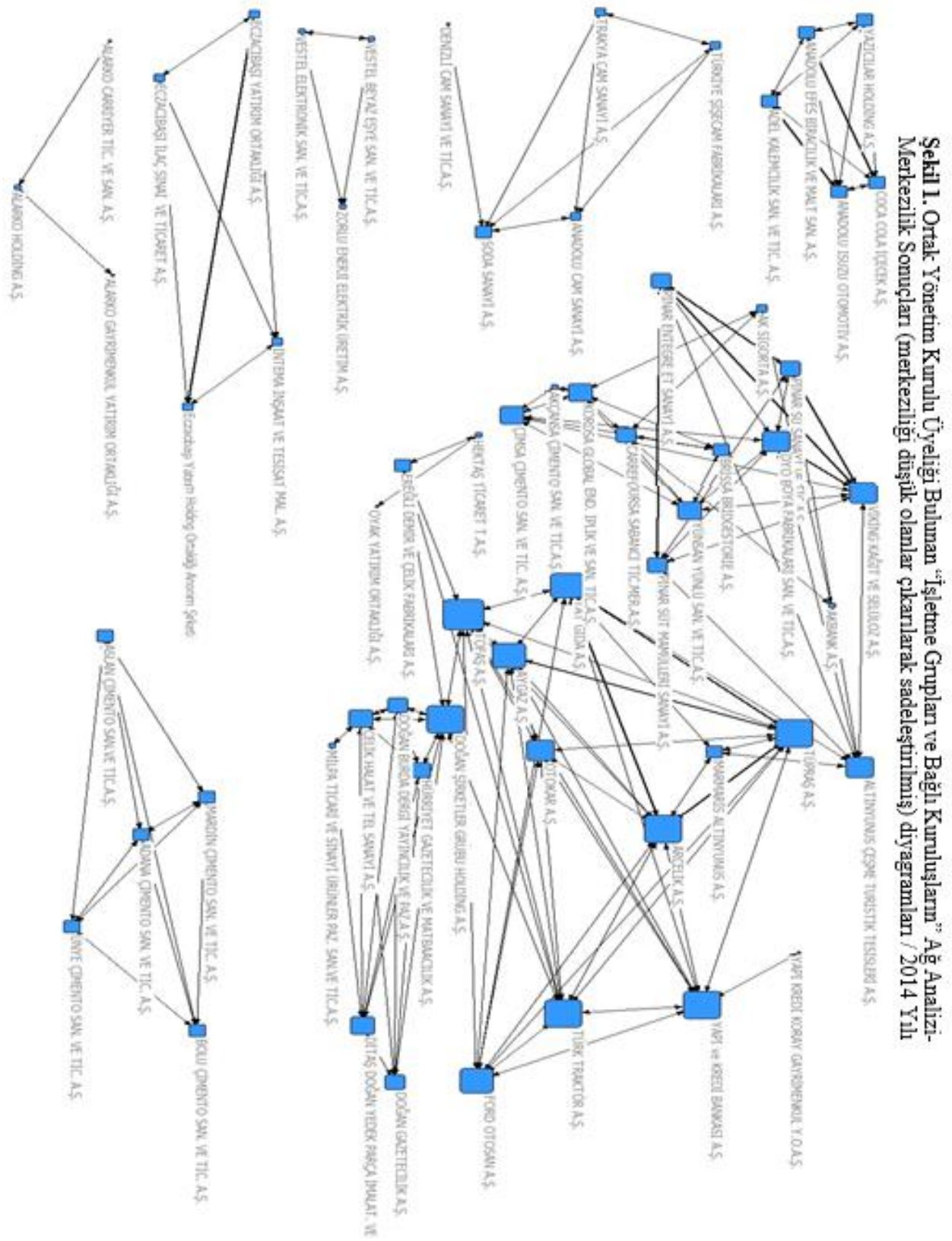

Birey Düzeyinde Ortak Yönetim Kurulu Üyeliği Bulunan "Yönetim Kurulu Üyeleri” İçin Sosyal A ̆g Analizi -Merkezilik- Sonuçları

Ortak yönetim kurulu üyeliği bulunan yönetim kurulu üyelerine ait merkezilik puanları ve merkezilik puanlarına dair tanımlayıcı istatistikler Tablo 2'de sunulmaktadır. 
Tablo 2. Ortak Yönetim Kurulu Üyeliği Bulunan "Yönetim Kurulu Üyelerinin” Merkezilik Puanları ve Merkezilik Puanlarına Dair Tanımlayıcı İstatistikler

\begin{tabular}{|c|c|c|c|c|c|}
\hline \multirow{2}{*}{ İşletme Grupları } & \multirow{2}{*}{ Kurul Üyeleri } & \multicolumn{2}{|c|}{ Derece } & \multicolumn{2}{|c|}{ Normlu Derece } \\
\hline & & 2011 & 2014 & 2011 & 2014 \\
\hline Koç Holding & 1.Osman Turgay Durak & 69.000 & 85.000 & 3.628 & 5.105 \\
\hline Koç Holding & 2.Mustafa Rahmi Koç & 51.000 & 55.000 & 2.681 & 3.303 \\
\hline Koç Holding & 3.Mustafa Vehbi Koç & 51.000 & 56.000 & 2.681 & 3.363 \\
\hline Koç Holding & 4.Temel Kamil Atay & 49.000 & 34.000 & 2.576 & 2.042 \\
\hline Doğan Holding & 5.Yahya Üzdiyen & 46.000 & 40.000 & 2.419 & 2.402 \\
\hline Koç Holding & 6.Ali Yıldırım Koç & 45.000 & 47.000 & 2.366 & 2.823 \\
\hline Koç Holding & 7.Mehmet Ömer Koç & 40.000 & 42.000 & 2.103 & 2.523 \\
\hline Koç Holding & 8.Semehat Sevim Arsel & 39.000 & 39.000 & 2.050 & 2.342 \\
\hline Koç Holding & 9.Bülent Bulgurlu & 39.000 & --- & 2.050 & -- \\
\hline Anadolu Holding & 10.Tuncay Özilhan & 38.000 & 46.000 & 1.998 & 2.763 \\
\hline Anadolu-Zorlu & 11.Recep Y1lmaz Argüden & 37.000 & --- & 1.945 & --- \\
\hline Yaşar Holding & 12.Mehmet Aktaş & 34.000 & 30.000 & 1.788 & 1.802 \\
\hline Yaşar Holding & 13.İdil Yiğitbaşı & 34.000 & 36.000 & 1.788 & 2.162 \\
\hline Anadolu Holding & 14.Süleyman Vehbi Yazıcı & 34.000 & 30.000 & 1.788 & 1.802 \\
\hline Anadolu Holding & 15.İbrahim Yazıcı & 34.000 & 30.000 & 1.788 & 1.802 \\
\hline Doğan Holding & 16.Hanzade V. D. Boyner & 33.000 & --- & 1.735 & -- \\
\hline Anadolu Holding & 17.Salih Metin Ecevit & 33.000 & 51.000 & 1.735 & 3.063 \\
\hline Anadolu Holding & 18.Tülay Aksoy & 29.000 & 25.000 & 1.525 & 1.502 \\
\hline Yaşar Holding & 19.Yılmaz Gökoğlu & 28.000 & 29.000 & 1.472 & 1.742 \\
\hline Sabancr Holding & 20.Faruk Bilen & 27.000 & --- & 1.420 & --- \\
\hline Koç Holding & 21.Ahmet F. Ashaboğlu & 27.000 & --- & 1.420 & --- \\
\hline Doğan Holding & 22.Vuslat Doğan Sabancı & 26.000 & --- & 1.367 & --- \\
\hline Şişecam Holding & 23.Zeynep Hansu Uçar & 26.000 & --- & 1.367 & --- \\
\hline Oyak Holding & 24.Celalettin Çağlar & 26.000 & 29.000 & 1.367 & 1.742 \\
\hline Koç-Doğan & 25.Taylan Bilgel & 24.000 & --- & 1.262 & --- \\
\hline Anadolu Holding & 26.Mehmet Cem Kozlu & 24.000 & --- & 1.262 & --- \\
\hline Koç Holding & 27.Kudret Önen & 23.000 & 28.000 & 1.209 & 1.682 \\
\hline Sabanci Holding & 28.Cezmi Kurtuluş & 23.000 & --- & 1.209 & --- \\
\hline Yaşar Holding & 29.Hakkı Hikmet Altan & 23.000 & --- & 1.209 & --- \\
\hline Sabancı Holding & 30.Mehmet Nurettin Pekarun & 23.000 & --- & 1.209 & --- \\
\hline Koç, Doğan, Oyak & 31. Ali Aydın Pandır & --- & 36.000 & --- & 2.162 \\
\hline Anadolu Holding & 32.Kamil Ömer Bozer & --- & 35.000 & --- & 2.102 \\
\hline Anadolu Holding & 33.Ahmet Cemal Dördüncü & --- & 34.000 & --- & 2.042 \\
\hline Anadolu Holding & 34.Mehmet Hurşit Zorlu & --- & 33.000 & --- & 1.982 \\
\hline Sabancı Holding & 35.Muhterem Kaan Terzioğlu & --- & 27.000 & --- & 1.622 \\
\hline Eczacıbaşı H. & 36.Ferit Bülent Eczacıbaşı & --- & 26.000 & --- & 1.562 \\
\hline Eczacıbaşı $H$. & 37.Mustafa Sacit Basmacı & --- & 26.000 & --- & 1.562 \\
\hline Sabance Holding & 38.Barış Oran & --- & 26.000 & --- & 1.562 \\
\hline Koç Holding & 39.Kutsan Çelebican & --- & 25.000 & --- & 1.502 \\
\hline Koç Holding & 40.Gökçe Bayındır & --- & 25.000 & --- & 1.502 \\
\hline Anadolu Holding & 41.Nilgün Yazıc1 & --- & 25.000 & --- & 1.502 \\
\hline Koç Holding & 42.İsmail Cenk Çimen & --- & 24.000 & --- & 1.441 \\
\hline \multirow{11}{*}{ İstatistikler } & Ortalama & 11.113 & 11.814 & 0.584 & 0.710 \\
\hline & Std. Sap. & 8.916 & 9.483 & 0.469 & 0.570 \\
\hline & Toplam & 3.534 .000 & 3.946 .000 & 185.804 & 236.997 \\
\hline & Varyans & 79.497 & 89.924 & 0.220 & 0.324 \\
\hline & SSQ & 64.554 .000 & 76.654 .000 & 178.444 & 276.507 \\
\hline & MCSSQ & 25.279 .924 & 30.034 .490 & 69.880 & 108.341 \\
\hline & Öklid Normu & 254.075 & 276.865 & 13.358 & 16.629 \\
\hline & Minimum & 3.000 & 4.000 & 0.158 & 0.240 \\
\hline & Maximum & 69.000 & 85.000 & 3.628 & 5.105 \\
\hline & Ağ Merkezciliği (2011):\%3.06 & & & & \\
\hline & Ağ Merkezciliği (2014):\%4.42 & & & & \\
\hline
\end{tabular}

A $\breve{g}$ Analizi merkezilik faktörü açısından işletme gruplarının yönetim kurullarında yer alan yönetim kurulu üyeleri bağlamında incelendiğinde (Tablo 2) örneklemde yer alan 10 işletme grubuna bağlı 61 işletmenin 2011 yılı için 318, 2014 yılı için 334 yönetim kurulu üyesinin merkezilik derecesi analiz edilmiş ve 
bu analiz sonucunda 2011 y1l için 82, 2014 y1lı içinse 101 yönetim kurulu üyesinin merkezilik derecesi açısından anlamlı sonuçlar içerdiği bulgusuna ulaşılmıştır. Analiz bulguları raporlanırken (Tablo 2) merkeziliği daha iyi görebilmek ve yönetim kurulu üyelerinin merkezilik açısından önem sıralamalarını kıyaslayabilmek adına 2011 ve 2014 yılları için anlamlılık açısından işletme gruplarının yönetim kurullarında yer alan merkeziliği en fazla olan ilk 30'ar yönetim kurulu üyesine dair değerler ilgili tabloda sunulmuştur. Tabloya ilişkin önemli bulgu 2014 yılına ait toplam merkezilik skorunun $(M D=3946.000) 2011$ y1lı merkezilik skoruna $(\mathrm{MD}=3534.000)$ kiyasla belirgin bir şekilde artış göstermesi ve 2011 yılında 82 olan ortak yönetim kurulu üye sayısının 2014 yılında 101'e çıkmasıdır.

Ortak yönetim kurulu üyeliği bulunan yönetim kurulu üyelerine ait ăg analizi merkezilik sonuç diagramları Şekil 2'de sunulmaktadır. Şekil 2'deki ă̆ diyagramına bakıldığında, yönetim kurulu üyeleri arasından Osman Turgay Durak en büyük simgeyle merkeziliğin en yoğun yaşandığı üye olarak karşımıza çıkmaktadır. Osman Turgay Durak'ın Arçelik A.Ş.(11), Aygaz A.Ş.(8), Ford Otomotiv Sanayi A.Ş.(13), Otokar Otomotiv ve Savunma S.A.Ş.(8), TOFAŞ Türk Otomobil Fabrikası A.Ş.(11), Türk Traktör ve Ziraat Makinaları A.Ş.(9), Yapı ve Kredi Bankası A.Ş.(11), Tüpraş Türkiye Petrol Rafinerileri A.Ş.(14) olmak üzere toplamda 85 Yönetim Kurulu üyesiyle bağlantısı bulunmaktadır.

Koç Holding' in çeşitli işletmelerinin yönetim kurullarında aile üyesi olarak görev yapan Mustafa Vehbi Koç 2011 yılında merkeziliğin en yoğun yaşandığı üçüncü, 2014 yılında ise ikinci aktör olarak karşımıza çıkmaktadır. Mustafa Vehbi Koç'un Arçelik A.Ş. (11), TOFAŞ Türk Otomobil Fabrikası A.Ş. (11), Tat Gıda Sanayi A.Ş.(9), Yap1 ve Kredi Bankası A.Ş.(11), Tüpraş Türkiye Petrol Rafinerileri A.Ş.(14) olmak üzere toplamda 56 yönetim kurulu üyesiyle bağlantıs1 bulunmaktadır. Bağlantılı olduğu üyelerin tamamının Koç Holdinge bağlı işletmelerin yönetim kurullarında yer alan üyeler olduğu görülmektedir.

Mustafa Rahmi Koç, Koç Holdingin çeşitli işletmelerinde aile üyesi olarak görev yapan merkezilik açısından diyagramda büyük sembollerle gösterilen 3 . yönetim kurulu üyesidir. Mustafa Rahmi Koç'un Arçelik A.Ş. (11), Aygaz A.Ş.(8), Ford Otomotiv Sanayi A.Ş.(13), Tat Gıda Sanayi A.Ş.(9), Tüpraş Türkiye Petrol Rafinerileri A.Ş.(14) olmak üzere toplamda 55 yönetim kurulu üyesiyle bağlantısı bulunmaktadır. Bağlantılı olduğu üyelerin tamamının Koç Holdinge bağlı işletmelerin yönetim kurullarında yer alan üyeler olduğu görülmektedir.

Salih Metin Ecevit merkezilik açısından 4. sırada yer alan yönetim kurulu üyesi olarak görülmektedir. Coca Cola İçecek A.Ş.(11), Anadolu Efes Biracilık ve Malt Sanayi A.Ş.(10), Anadolu Isuzu Otomotiv Sanayi ve Ticaret A.Ş.(13), Adel Kalemcilik Ticaret ve Sanayi A.Ş.(12) ve Yazıcılar Holding A.Ş.(5) olmak üzere toplamda 51 yönetim kurulu üyesiyle bağlantısı bulunmaktadır. Bağlantılı olduğu üyelerin tamamının Anadolu Holdinge bağlı işletmelerin yönetim kurullarında yer alan üyeler olduğu görülmektedir.

Ali Yıldırım Koç, Koç Holdingin çeşitli işletmelerinde aile üyesi olarak görev yapan merkezilik açısından diyagramda büyük sembollerle gösterilen 5 . 
yönetim kurulu üyesidir. Ali Yıldırım Koç'un Arçelik A.Ş. (11), Ford Otomotiv Sanayi A.Ş.(13), Tat Gıda Sanayi A.Ş.(9), Tüpraş Türkiye Petrol Rafinerileri A.Ş.(14) olmak üzere toplamda 47 yönetim kurulu üyesiyle bağlantısı bulunmaktadır. Bağlantılı olduğu üyelerin tamamının Koç Holding'e bağlı işletmelerin yönetim kurullarında yer alan üyeler olduğu görülmektedir.

Tuncay Özilhan Anadolu Holdingin çeşitli işletmelerinde aile üyesi olarak merkezilik açısından 6. Sırada yer alan yönetim kurulu üyesi olarak karşımıza çıkmaktadır. Tuncay Özilhan'ın Coca Cola İçecek A.Ş.(11), Anadolu Efes Biracılık ve Malt Sanayi A.Ş.(10), Anadolu Isuzu Otomotiv Sanayi ve Ticaret A.Ş.(13), Adel Kalemcilik Ticaret ve Sanayi A.Ş.(12) olmak üzere toplamda 46 yönetim kurulu üyesiyle bağlantısı bulunmaktadır. Bağlantılı olduğu üyelerin tamamının Anadolu Holding'e bağlı işletmelerin yönetim kurullarında yer alan üyeler olduğu görülmektedir.

334 yönetim kurulu üyesinin merkezilik açısından sıralanmasının ilk 40 listesine bakıldığında 14 yönetim kurulu üyesinin Koç Holdige bağlı işletmelerde üye olduğu onu 10 yönetim kurulu üyesiyle Anadolu Holdinge bağlı yönetim kurulu üyelerinin takip ettiği görülmektedir. 10. Sırada ise Koç Holding, Doğan Holding ve Oyak Holdingin çeşitli işletmelerinin yönetim kurullarında yer alan Ali Aydın Pandır göze çarpmaktadır. Yaşar Holding ve Sabancı Holdinge bağlı işletmelerde yönetim kurulu üyeliği olan 5'er kişinin, Oyak Holding ve Eczacıbaşı Holdinge bağlı işletmelerde yönetim kurulu üyeliği olan 2'şer kişinin, Doğan Holdinge bağlı işletmelerde yönetim kurulu üyeliği olan 1 kişinin de bu siralama da yer aldığı görülmektedir.

334 yönetim kurulundan oluşan merkezilik ağ analizine bakıldığında ilk üç kişinin (Osman Turgay Durak, Mustafa Vehbi Koç ve Mustafa Rahmi Koç) sadece Koç Holdinge bağlı işletmelerde yönetim kurulu üyeliğinin olduğunu görülmektedir. $\mathrm{Bu}$ veriler 1şı̆̆ında merkeziliğin örneklemde yer alan işletme grupları açısından Koç Holding Bünyesinde daha yoğun yaşandığı söylenebilmektedir. Merkezilik ağ analizine bakıldığında ilk beş kişinin (Osman Turgay Durak, Mustafa Vehbi Koç Mustafa Rahmi Koç, Salih Metin Ecevit ve Ali Yıldırım Koç) dördünün Koç Holding'le, birinin ise Anadolu Holdingle ilişkisi olduğu görülmektedir. Merkezi durumda olan ilk 5 aktörün 3 'ünün aile üyelerinden 2'sinin ise uzun y1llar ailede çalışarak artık aileden biri gibi görülen üyelerden oluşturulduğu görülmektedir. İlk 10 aktöre baktı̆̆ımızda ise 6 üyenin $(2,3 ., 5 ., 6 ., 7$. ve 9.,) aile üyelerinden, 1 üyenin(10.) 3 holdingle ilişkisi olduğundan icracı ve ya bağımsız üyeden, 3 üyenin de (1.,4.,ve 8.) uzun yıllar ailede çalışarak artık aileden biri gibi görülen CEO'lardan oluştuğu görülmektedir.

Tüm ağ dikkate alındığında ise holdinglerde en merkezi aktörlerin genellikle aile üyelerinden ya da otomotiv sektöründe geniş deneyimlere sahip olan şirket CEO'larından oluştuğu görülmektedir. Merkeziliğin en yoğun yaşandığ aktör olan Osman Turgay Durak'ın Koç Holding'in CEO'su ve uzun yıllar otomotiv sektöründe deneyimleri olduğu, 4. Sırada yer olan Salih Metin Ecevit'in otomotiv sektöründe çeşitli işletmelerde CEO’luk yaptığı emekli olarak hala yönetim kurulunda bulunduğu, 8. sıradaki Yahya Üzdiyen'inde yine otomotiv 
sektöründe uzun y1llar çalışarak CEO'luk görevinde bulunduğu görülmektedir. Ağa bir bütün olarak bakıldığında, 2011 yılı ăg merkezilik değerinin ortak yönetim kurulu üyeliği bulunan işletme grupları için \% 5,10 ortak yönetim kurulu üyeliği bulunan yönetim kurulu üyeleri için \% 3.06 olduğu, 2014 yılı ağ merkezilik değerinin ortak yönetim kurulu üyeliği bulunan işletme grupları için \% 4.97 ortak yönetim kurulu üyeliği bulunan yönetim kurulu üyeleri için \% 4.42 olduğu görülmektedir ki bu durumda önemli bir yoğunlaşma miktarının ya da merkezciliğin olmadığı anlaşılmaktadır. Diğer bir ifadeyle bireysel aktörlerin gücünün ağ içinde ortalamanın altında bir değişkenlik gösterdiği görülmüştür. Bu bağlamda, aktörlerin ağ içinde yayılımının çok fazla olmadığını ve aktörlerin ağda çok fazla aktif olmadıklarını söylemek mümkündür
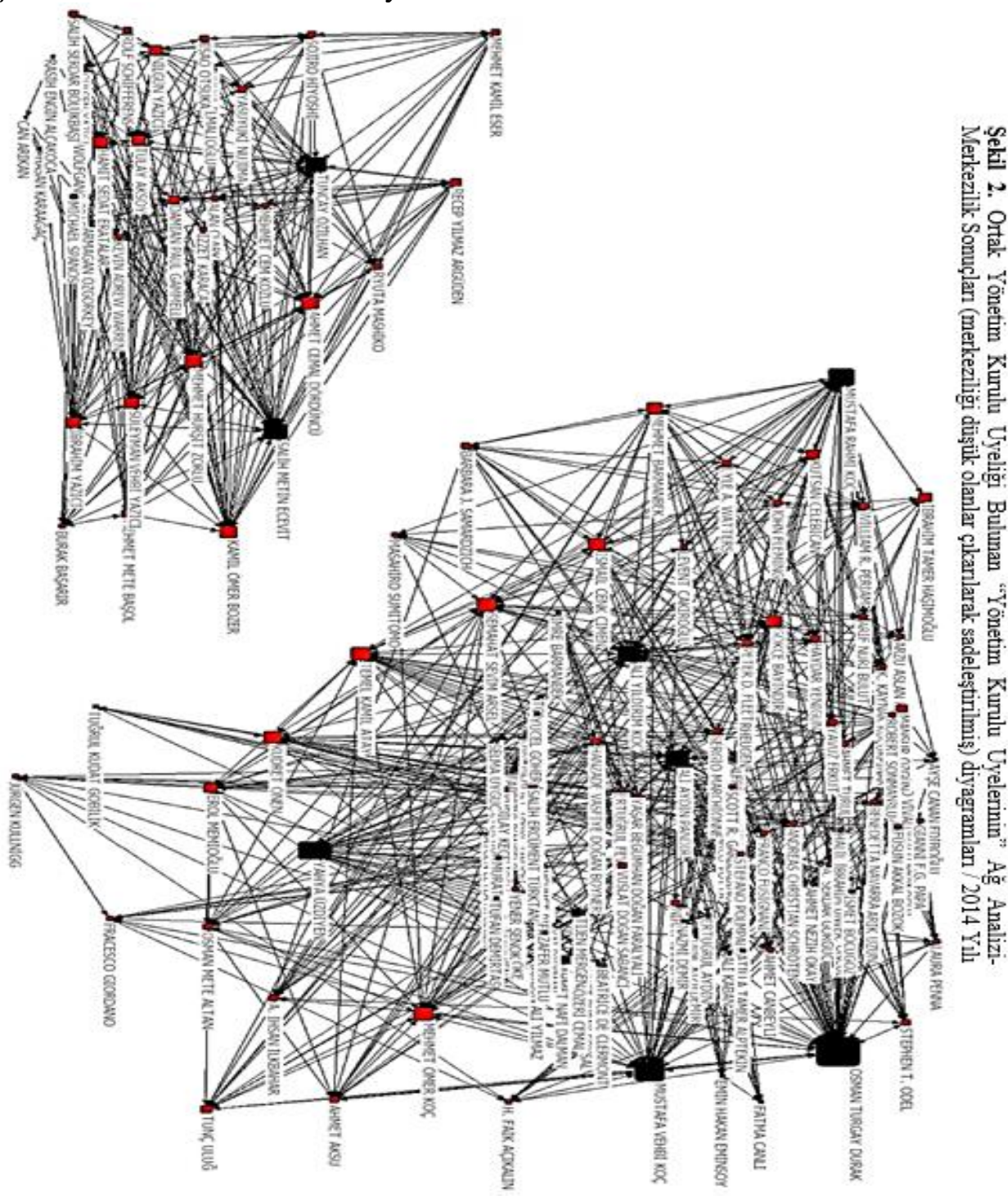


\section{Firma Düzeyinde Ortak Yönetim Kurulu Üyesi Bulunan "İşletme Grupları Ve} Bağlı Kuruluşlar" İçin Sosyal Ăg Analizi -Arasındalık- Sonuçları

Ortak yönetim kurulu üyeliği bulunan "işletme grupları ile bağlı kuruluşlarına" ait arasındalık puanları ve arasındalık puanlarına dair tanımlayıcı istatistikler Tablo 3'de ağ analizi- arasındalık sonuç diagramları ise Şekil 3'de sunulmaktadır. Tabloda yer alan normalize edilmiş arasındalık (normalized betweenness) değerleri arasındalık değerinin yüzde olarak ifade edilen azami muhtemel arasındalığa bölümü ile elde edilmektedir. İşletme grupları ve bağlı kuruluşlara dair ağ analizi arasındalık faktörü açısından incelendiğinde (Tablo 3), 2011 yilında örneklemde yer alan 10 işletme grubundan 4'ünün ve bu işletme gruplarına bağlı 61 işletmeden 9'unun, 2014 yılında ise 10 işletme grubundan 5 'inin ve bu işletme gruplarına bağlı 61 işletmeden 13'ünün arasındalık açısından anlamlı sonuçlar içerdiği görülmektedir ${ }^{4}$. Tabloya ilişkin önemli bir bulgu 2014 y1lına ait toplam arasındalık skorunun $(\mathrm{MD}=1.687 .000), 2011$ y1lına ait toplam arasındalık skoruna $(\mathrm{MD}=516.000)$ ve 2014 yılına ait arasındalık oranının $(\%$ 14.84), 2011 yılına ait arasındalık oranına (\% 7.96) kıyasla belirgin bir şekilde artış göstermesidir.

Tablo 3. Ortak Yönetim Kurulu Üyeliği Bulunan "İşletme Grupları ve Bağlı Kuruluşların” Arasındalık Puanları ve Arasındalık Puanlarına Dair Tanımlayıcı İstatistikler

\begin{tabular}{|c|c|c|c|c|c|}
\hline \multirow{2}{*}{ İşletme Gruplart } & \multirow{2}{*}{ Bağlı Kuruluşlar } & \multicolumn{2}{|c|}{ Arasındalık } & \multicolumn{2}{|c|}{ Norm Arasındalık } \\
\hline & & 2011 & 2014 & 2011 & 2014 \\
\hline Koç Holding & 1.Otokar A.Ș. & 147.000 & 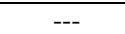 & 8.305 & --- \\
\hline Yaşar Holding & $\begin{array}{l}\text { 2.Altınyunus Çeşme Turistik } \\
\text { Tesisleri A.Ş. }\end{array}$ & 102.476 & 286.000 & 5.790 & 16.158 \\
\hline Koç Holding & 3.Tüpraş A.Ş. & 48.952 & --- & 2.766 & --- \\
\hline Doğan Holding & $\begin{array}{l}\text { 4.Ditaş Doğan Yedek Par. İm. } \\
\text { Tekstil A.Ş. }\end{array}$ & 47.500 & --- & 2.684 & --- \\
\hline Doğan Holding & $\begin{array}{l}\text { 5.Doğan Şirketler Grubu } \\
\text { Holding A.Ş. }\end{array}$ & 47.500 & 202.000 & 2.684 & 11.412 \\
\hline Koç Holding & 6.Tat Gıda A.Ş. & 28.833 & --- & 1.629 & --- \\
\hline Oyak Holding & $\begin{array}{l}\text { 7.Ereğli Demir ve Çelik } \\
\text { Fabrikaları A.Ş. }\end{array}$ & 24.000 & 66.000 & 1.356 & 3.729 \\
\hline Koç Holding & 8.Marmaris Altınyunus A.Ş. & 15.143 & --- & 0.856 & --- \\
\hline Koç Holding & 9.Yapı ve Kredi Bankası A.Ş. & 13.786 & 37.833 & 0.779 & 2.137 \\
\hline Koç Holding & 10.Tat Gıda A.Ş. & -- & 262.867 & -- & 14.851 \\
\hline Koç Holding & 11.Tofaş A.Ş. & -- & 213.933 & --- & 12.087 \\
\hline Yaşar Holding & $\begin{array}{l}\text { 12.Dyo Boya Fabrikaları San. } \\
\text { ve Tic.A.Ş. }\end{array}$ & --- & 104.000 & --- & 5.876 \\
\hline Yaşar Holding & 13.Viking Kağıt ve Selüloz A.Ş. & -- & 104.000 & --- & 5.876 \\
\hline Sabancı Holding & $\begin{array}{l}\text { 14.Yünsan Yünlü San. ve } \\
\text { Tic.A.Ş. }\end{array}$ & --- & 103.250 & --- & 5.833 \\
\hline Sabancı Holding & $\begin{array}{l}\text { 15.Çimsa Çimento San. ve Tic. } \\
\text { A.Ş. }\end{array}$ & -- & 66.333 & --- & 3.748 \\
\hline Koç Holding & 16.Türk Traktör A.Ş. & --- & 42.900 & --- & 2.424 \\
\hline Sabancı Holding & $\begin{array}{l}\text { 17.Carrefoursa Sabancı } \\
\text { Tic.Mer.A.Ş. }\end{array}$ & --- & 42.083 & --- & 2.378 \\
\hline Oyak Holding & 18.Hektaş Ticaret T.A.Ş. & --- & 34.000 & --- & 1.921 \\
\hline \multirow{4}{*}{ Istatistikler } & Ortalama & 8.459 & 27.656 & 0.478 & 1.562 \\
\hline & Std Sap. & 24.495 & 62.745 & 1.384 & 3.545 \\
\hline & Toplam & 516.000 & 1.687 .000 & 29.153 & 95.311 \\
\hline & Varyans & 599.985 & 3.936 .891 & 1.915 & 12.566 \\
\hline
\end{tabular}

${ }^{4}$ İlgili tablolarda sadece arasındalık açısından anlamlı sonuçlar içerdiği sunulan bağlı kuruluşlar sunulmuştur. 
Yönetim ve Ekonomi 26/2 (2019) 625-650

$\begin{array}{lcccc}\text { SSQ } & 40.963 .914 & 286.805 .563 & 130.754 & 915.464 \\ \text { MCSSQ } & 36.599 .063 & 240.150 .344 & 116.822 & 766.543 \\ \text { Öklid Normu } & 202.39 & 535.542 & 11.435 & 30.257 \\ \text { Minimum } & 0.000 & 0.000 & 0.000 & 0.000 \\ \text { Maximum } & 147.000 & 286.000 & 8.305 & 16.158\end{array}$

Ağ Merkezciliği (2011): \%7.96

A $\breve{g}$ Merkezciliği (2014): \%14.84
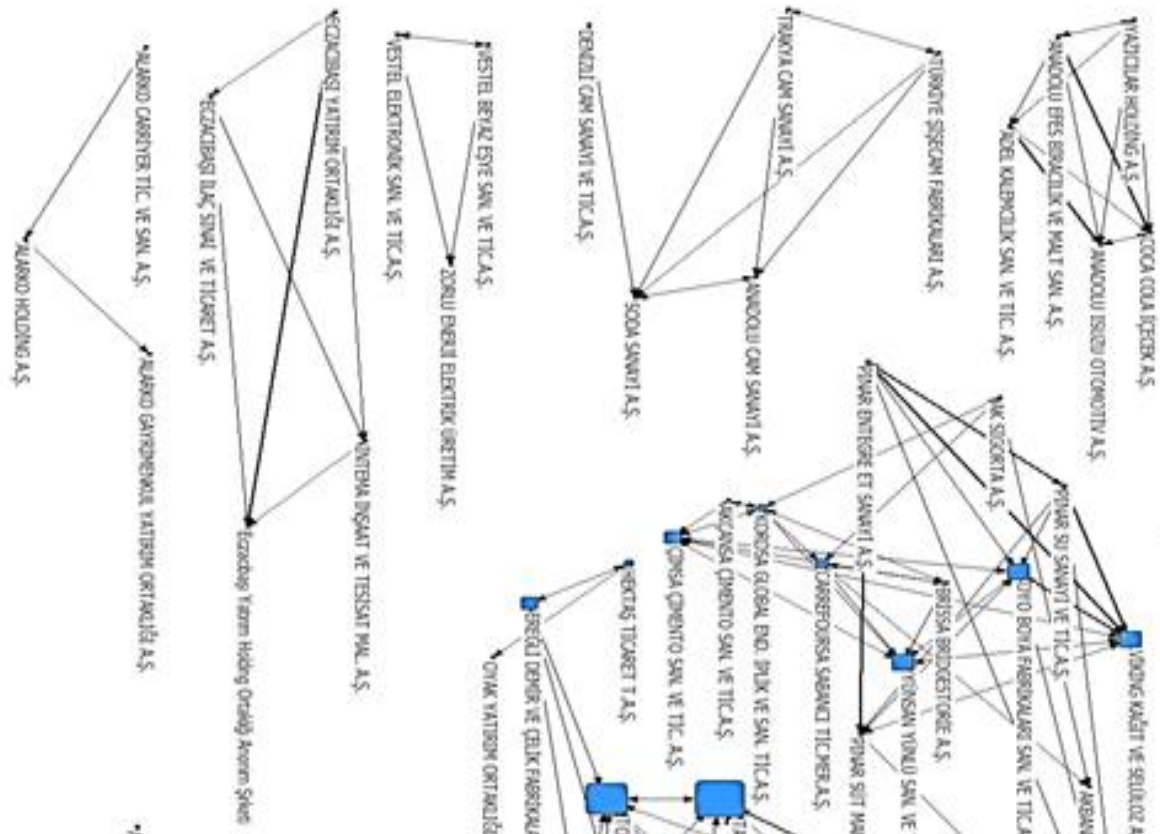

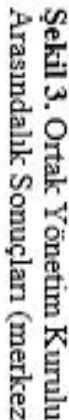
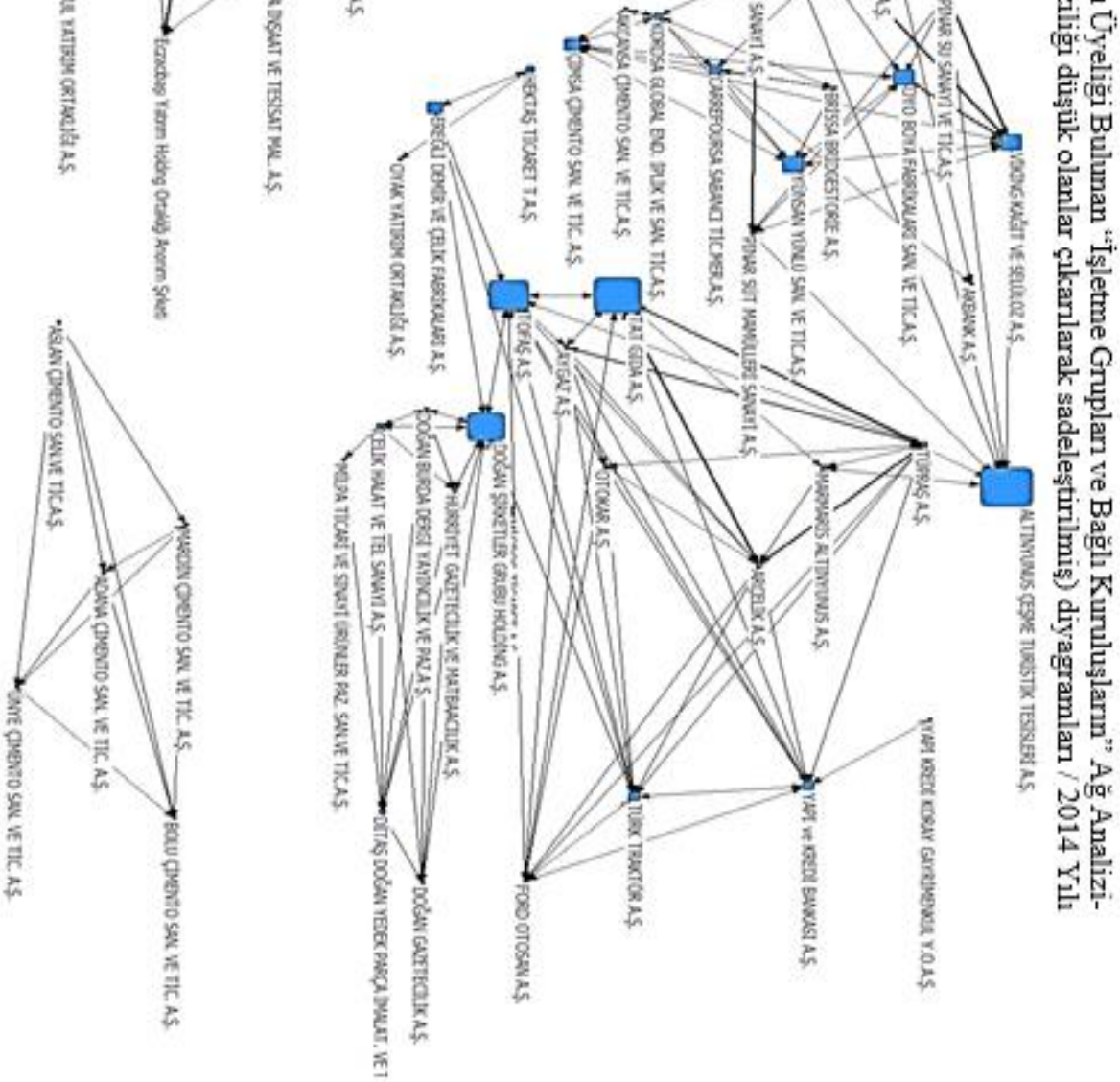
2014 Ağ Diyagramı arasındalık açısından işletme grupları arasında incelendiğinde (Şekil 3), örneklemde yer alan 10 işletme grubunun 4'ünün sadece kendi işletme grupları içerisinde ortak yönetim kurulu üyeliği gerçekleştirdikleri, diğer işletme gruplarıyla ortak yönetim kurulu ilişkilerinin olmadığ 1,5 işletme grubunun da hem işletme grubu içerisinde hem de işletme grubu dişarısındaki işletmelerle ortak yönetim kurulu üyeliği gerçekleştirdikleri görülmektedir. İşletme gruplarından 1'inin kendi bünyesinde yer alan 6 işletmesi bulunmaktadır ve bu işletmeler içerisinde 5'inin birbirleriyle ortak yönetim kurulu üyeliği gerçekleştirdiği 1'inin ise işletmenin dâhil olduğu işletme grubu içerisinde ortak yönetim kurulu üyeliği bulunmazken başka bir işletme grubu bünyesindeki 1 işletmeyle doğrudan ortak yönetim kurulu üyeliği gerçekleştirdiği görülmektedir.

\section{Birey Düzeyinde Ortak Yönetim Kurulu Üyeliği Bulunan "Yönetim Kurulu Üyeleri" İçin Sosyal A ̆g Analizi -Arasındalık- Sonuçları}

Ortak yönetim kurulu üyeliği bulunan yönetim kurulu üyelerine ait arasındalık puanları ve arasındalık puanlarına dair tanımlayıcı istatistikler Tablo 4'de 2014 yılına ait ortak yönetim kurulu üyeliği bulunan yönetim kurulu üyelerine dair ağ analizi arasındalık sonuç diyagramları ise Şekil 4'de sunulmaktadır.

Tablo 4. Ortak Yönetim Kurulu Üyeliği Bulunan “Yönetim Kurulu Üyelerinin” Arasındalık Puanları ve Arasındalık Puanlarına Dair Tanımlayıcı İstatistikler

\begin{tabular}{|c|c|c|c|c|c|}
\hline \multirow{2}{*}{$\begin{array}{l}\text { İșletme } \\
\text { Grupları }\end{array}$} & \multirow{2}{*}{ Kurul Üyeleri } & \multicolumn{2}{|c|}{ Arasındalık } & \multicolumn{2}{|c|}{ Norm Arasındalık } \\
\hline & & 2011 & 2014 & 2011 & 2014 \\
\hline Koç Holding & 1. Osman Turgay Durak & 4.193 .455 & 3.366 .300 & 8.373 & 6.090 \\
\hline Koç - Doğan & 2. Taylan Bilgel & 3.708 .000 & --- & 7.403 & --- \\
\hline Oyak Holding & 3. Nihat Karadağ & 3.094 .000 & 1.746 .000 & 6.177 & 3.159 \\
\hline Oyak Holding & 4. Serpil Güngör Erdoğan & 2.604 .000 & --- & 5.199 & --- \\
\hline Oyak Holding & 5. Celalettin Çağlar & 1.390 .833 & --- & 2.777 & --- \\
\hline Koç - Yaşar & 6. İbrahim Tamer Haşimoğlu & 1.128 .120 & 8.929 .733 & 2.252 & 16.154 \\
\hline Doğan Holding & 7. Yahya Üzdiyen & 1.017 .250 & 4.641 .333 & 2.031 & 8.396 \\
\hline Koç - Yaşar & 8. Ali Tarık Uzun & 862.679 & --- & 1.722 & --- \\
\hline Doğan Holding & 9. Hanzade Vasfiye D. Boyner & 804.333 & 513.000 & 1.606 & 0.928 \\
\hline Koç Holding & 10. Ahmet F. Ashaboğlu & 762.672 & 390.000 & 1.523 & 0.706 \\
\hline Koç Holding & 11. Mustafa Vehbi Koç & 728.145 & 7.584 .446 & 1.454 & 13.721 \\
\hline Oyak Holding & 12. Güney Arık & 718.333 & --- & 1.434 & --- \\
\hline Koç Holding & 13. Temel Kamil Atay & 613.950 & 458.394 & 1.226 & 0.829 \\
\hline Yaşar Holding & 14. Mehmet Aktaş & 506.739 & 3.896 .947 & 1.012 & 7.050 \\
\hline Yaşar Holding & 15. İdil Yiğitbaş1 & 506.739 & 3.896 .947 & 1.012 & 7.050 \\
\hline Koç Holding & 16. Mustafa Rahmi Koç & 441.815 & 771.424 & 0.882 & 1.396 \\
\hline Koç Holding & 17. Ali Yıldırım Koç & 422.882 & 709.567 & 0.844 & 1.284 \\
\hline Doğan Holding & 18. Vuslat Doğan Sabancı & 408.333 & 513.000 & 0.815 & 0.928 \\
\hline Anadolu-Zorlu & 19. Recep Yılmaz Argüden & 392.033 & --- & 0.783 & --- \\
\hline Koç Holding & 20. Kudret Önen & 389.138 & 389.923 & 0.777 & 0.705 \\
\hline Koç Holding & 21. Semahat Sevim Arsel & 385.419 & 757.672 & 0.770 & 1.371 \\
\hline $\begin{array}{l}\text { Sabancl } \\
\text { Holding }\end{array}$ & 22. Hayri Çulhacı & 360.286 & --- & 0.719 & --- \\
\hline $\begin{array}{l}\text { Sabancl } \\
\text { Holding }\end{array}$ & 23. Faruk Bilen & 307.370 & --- & 0.614 & --- \\
\hline $\begin{array}{l}\text { Sisecam } \\
\text { Holding }\end{array}$ & 24. Zeynep Hansu Uçar & 298.500 & --- & 0.596 & --- \\
\hline Koç Holding & 25. Carlo Vivaldi & 288.556 & 390.000 & 0.576 & 0.706 \\
\hline
\end{tabular}




\begin{tabular}{|c|c|c|c|c|c|}
\hline Koç-Yaşar ${ }^{*}$ & 26. Mehmet Ömer Koç & 259.282 & 379.262 & 0.518 & 0.686 \\
\hline $\begin{array}{l}\text { Sabancl } \\
\text { Holding }\end{array}$ & 27. Haluk Dinçer & 219.155 & --- & 0.438 & --- \\
\hline Zorlu Holding & 28. Olgun Zorlu & 210.333 & --- & 0.420 & --- \\
\hline $\begin{array}{l}\text { Sabance } \\
\text { Holding }\end{array}$ & 29. Seyfettin Ata Köseoğlu & 200.494 & 548.467 & 0.400 & 0.992 \\
\hline Sabanc1-Yaşar $^{* *}$ & 30. Mehmet Kahya & 191.589 & 7.606 .234 & 0.383 & 13.760 \\
\hline $\begin{array}{l}\text { Sisisecam } \\
\text { Holding }\end{array}$ & 31. Asuman Akman & 162.500 & --- & 0.324 & --- \\
\hline Yaşar Holding & 32. Hasan Girenes & 147.189 & --- & 0.294 & --- \\
\hline $\begin{array}{l}\text { Sabancl } \\
\text { Holding }\end{array}$ & 33. Mehmet Nurettin Pekarun & 133.815 & 1.036 .717 & 0.267 & 1.875 \\
\hline $\begin{array}{l}\text { Sabance } \\
\text { Holding }\end{array}$ & 34. Cezmi Kurtuluş & 133.815 & --- & 0.267 & --- \\
\hline Koç Holding & 35. Bülent Bulgurlu & 116.442 & --- & 0.232 & --- \\
\hline $\begin{array}{l}\text { Sabancl } \\
\text { Holding }\end{array}$ & 36. Bülent Bozdoğan & 109.256 & --- & 0.218 & --- \\
\hline $\begin{array}{l}\text { Koç-Doğan- } \\
\text { Oyak }\end{array}$ & 37. Ali Aydın Pandır & --- & 9.737 .923 & --- & 17.616 \\
\hline $\begin{array}{l}\text { Sabancl } \\
\text { Holding }\end{array}$ & 38. Barış Oran & --- & 4.003 .617 & --- & 7.243 \\
\hline $\begin{array}{l}\text { Sabancl } \\
\text { Holding }\end{array}$ & $\begin{array}{l}\text { 39. Muhterem Kaan } \\
\text { Terzioğlu }\end{array}$ & --- & 1.664 .675 & --- & 3.011 \\
\hline Anadolu-Doğan & 40. Tayfun Bayazıt & --- & 1.560 .000 & --- & 2.822 \\
\hline Oyak Holding & 41. Mustafa Dağüstü & --- & 796.000 & --- & 1.440 \\
\hline $\begin{array}{l}\text { Sabancl } \\
\text { Holding }\end{array}$ & 42. Neriman Ülsever & --- & 782.233 & --- & 1.415 \\
\hline $\begin{array}{l}\text { Sabancl } \\
\text { Holding }\end{array}$ & 43. Hayrullah Hakan Gürdal & --- & 690.000 & --- & 1.248 \\
\hline $\begin{array}{l}\text { Sabancl } \\
\text { Holding }\end{array}$ & 44. Hüsnü Paçacioğlu & --- & 424.267 & --- & 0.768 \\
\hline Koç Holding & 45. Adil G. Öztoprak & --- & 390.000 & --- & 0.706 \\
\hline Koç Holding & 46. İsmail Cenk Çimen & --- & 378.117 & --- & 0.684 \\
\hline Doğan Holding & 47. Salih Ercüment Türktan & --- & 274.667 & --- & 0.497 \\
\hline Doğan Holding & 48. Yener Şenok & --- & 259.333 & --- & 0.469 \\
\hline Koç Holding & 49. Gökçe Bayındır & --- & 246.779 & --- & 0.446 \\
\hline \multirow{10}{*}{ İstatistikler } & Ortalama & 102.560 & 215.380 & 0.205 & 0.390 \\
\hline & Std Sap. & 461.236 & 1.051 .135 & 0.921 & 1.902 \\
\hline & Toplam & 32.614 .000 & 71.937 .000 & 65.116 & 130.137 \\
\hline & Varyans & 212.738.391 & 1.104 .884 .000 & 0.848 & 3.616 \\
\hline & SSQ & $\begin{array}{c}70.995 .688 .00 \\
0\end{array}$ & $\begin{array}{c}384.525 .088 .00 \\
0\end{array}$ & $\begin{array}{c}283.00 \\
8\end{array}$ & 1.258 .404 \\
\hline & MCSSQ & $\begin{array}{c}67.650 .808 .00 \\
0\end{array}$ & $\begin{array}{c}369.031 .264 .00 \\
0\end{array}$ & $\begin{array}{c}269.67 \\
5\end{array}$ & 1.207 .698 \\
\hline & Öklid Normu & 8.425 .895 & 19.609.311 & 16.823 & 35.474 \\
\hline & Minimum & 0.000 & 0.000 & 0.000 & 0.000 \\
\hline & Maximum & 4.193 .455 & 9.737 .923 & 8.373 & 17.616 \\
\hline & 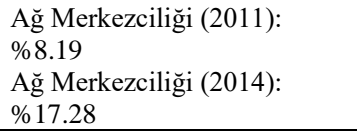 & & & & \\
\hline
\end{tabular}

\footnotetext{
"2011: Koç Holding -Yaşar Holding; 2014: Koç Holding

**2011: Yaşar Holding; 2014: Sabancı Holding - Yaşar Holding
} 
A $\breve{g}$ Analizi arasındalık faktörü açısından (Tablo 4) işletme gruplarının yönetim kurullarında yer alan yönetim kurulu üyeleri bağlamında incelendiğinde örneklemde yer alan 10 işletme grubuna bağlı 61 işletmenin 2011 y1lı için 318, 2014 y1lı için 334 yönetim kurulu üyesinin arasındalık derecesi analiz edilmiş ve bu analiz sonucunda 2011 y1lı için 36, 2014 y1lı içinse 33 yönetim kurulu üyesinin arasındalık derecesi açısından anlamlı sonuçlar içerdiği bulgusuna ulaşılmıştır. Tabloya ilişkin önemli bulgu 2014 y1lına ait toplam arasındalık skorunun (MD = 71.937.000) 2011 y1lı arasindalık skoruna $(\mathrm{MD}=32.614 .000)$ ve 2014 y1lına ait arasındalık oranının (\% 17.28) 2011 yılı arasındalık oranına (\% 8.19) kıyasla belirgin bir şekilde artı̧̧ göstermesidir. Bu durumda önemli bir yoğunlaşma miktarının ya da arasındalığın olmadığı anlaşılmaktadır. Diğer bir ifadeyle bireysel aktörlerin gücünün ağ içinde ortalamanın altında bir değişkenlik gösterdiği görülmüştür. Bu bağlamda, aktörlerin ağ içinde yayılımının çok fazla olmadığını ve aktörlerin ağda çok fazla aktif olmadıklarını söylemek mümkündür.

Ortak yönetim kurulu üyeliği bulunan yönetim kurulu üyelerine ait ăg analizi arasındalık sonuç diagramları Şekil 4'de sunulmaktadır. Şekilde merkeziğili düşşük olan kişiler çıkarılarak sadeleştirilmiştir 2014 ağ diyagramı arasındalık açısından işletme gruplarının yönetim kurullarında yer alan kişiler bağlamında incelendiğinde Şekil 4'te örneklemde yer alan 10 işletme grubunun 4'nün sadece kendi işletme grupları içerisinde ortak yönetim kurulu üyeliği gerçekleştirdiği diğer işletme gruplarıyla herhangi bir ortak yönetim kurulu üyeliklerinin olmadığ 1 görülmektedir. Ağ diyagramında daha anlamlı olan ortak yönetim kurulu üyeliklerini şekil olarak daha detaylı görebilmek adına bu 4 işletme grubu şekil dışında bırakılmıştır. İşletme gruplarından 1'inin kendi bünyesinde yer alan 6 işletmesi bulunmaktadır ve bu işletmeler içerisinde 5'inin birbirleriyle ortak yönetim kurulu üyeliği gerçekleştirdiği 1'nin ise işletmenin dahil olduğu işletme grubu içerisinde ortak yönetim kurulu üyeliği bulunmazken başka bir işletme grubu bünyesindeki 1 işletmeyle doğrudan ortak yönetim kurulu üyeliği gerçekleştirdiği görülmektedir ve bu üyelik de yine çoğunluğu görebilmek adına şekil dışında bırakılmıştır. Diğer 5 işletme grubunun da hem kendi içerisinde hem de dışarısındaki işletme gruplarıyla ortak yönetim kurulu üyeliği gerçekleştirdiği neticesiyle kişiler arasında görülen ortak yönetim kurulu ağ diyagramı iki kümeden oluşmaktadır. Birinci kümede sadece Anadolu İşletme Grubu bünyesinde yer alan işletmelerin (Migros hariç) yönetim kurulu üyeleri yer alırken ikinci kümede Oyak İşletme Grubunun, Sabancı İşletme Grubunun, Yaşar İşletme Grubunun, Doğan İşletme Grubunun ve Koç İşletme Grubunun bünyesinde yer alan işletmelerin yönetim kurulu üyeleri yer aldığı görülmektedir.

2014 yılında örneklemde yer alan işletme gruplarının yönetim kurullarında yer alan yönetim kurulu üyeleri arasında ortak yönetim kurulu üyeliğinde en fazla bulunan isim Ali Aydın Pandır'dır. Ali Aydın Pandır'ın özellikle otomotiv sektörü üzerinde geniş deneyimleri bulunmaktadır. Koç Holding bünyesinde yer alan Tofaş ve Türk Traktör'de iç üye olarak yönetim kurulunda görev yaparken, Doğan Holding bünyesinde Doğan Şirketler Grubu Holding A.Ş. ve Oyak Holding bünyesinde Ereğli Demir ve Çelik Fabrikaları T.A.Ş dışardan bağımsız üye olarak 
yönetim kurullarında görev yapmaktadır. Koç Holding bünyesinde yer alan TOFAŞ Türk Otomobil Fabrikası A.Ş. 12 yönetim kurulu üyesiyle, Türk Traktör ve Ziraat Makinaları A.Ş. 10 yönetim kurulu üyesiyle aynı yönetim kurulunda üye olmaları neticesinde ilişkileri bulunurken yönetim kurulunda yer alan diğer yönetim kurulu üyelerinin birbirlerine olan sinerjik etkisiyle Koç Holding bünyesinde yer alan 11 işletmenin tümünün yönetim kurulu üyeleriyle de ilişkisi bulunmaktadır. Ayrıca Doğan Holding bünyesinde Doğan Şirketler grubunda 9 yönetim kurulu üyesiyle ve Oyak Holding bünyesinde Ereğli Demir Çelikte 9 yönetim kurulu üyesiyle holdingler arasında bir ilişkisi bulunurken yönetim kurulunda yer alan diğer yönetim kurulu üyelerinin yine sinerjik etkisiyle Doğan Holding bünyesinde yer alan 7, Oyak Holding bünyesinde yer alan 8 işletmenin tüm yönetim kurulu üyeleriyle holdingler arasında yönetim kurulu üyeleriyle de ilişkisi bulunmaktadır.

İkinci sırada göze çarpan isim İbrahim Tamer Haşimoğlu'dur. İbrahim Tamer Haşimoğlu'nun özellikle stratejik planlama, turizm, gıda ve parakende sektörü üzerine geniş deneyimleri bulunmaktadır. Koç Holding bünyesinde yer alan Marmaris ve Tat Gıda'da iç üye olarak yönetim kurulunda görev yaparken, Yaşar Holding bünyesinde Altınyunus Turistik Tesisler işletmesinde yönetim kurulu üyesi olarak yönetim kurullarında görev yapmaktadır. Koç Holding bünyesinde yer alan Marmariste 6, Tat Gıda da 10 yönetim kurulu üyesiyle bir ilişkisi bulunurken yönetim kurulunda yer alan diğer yönetim kurulu üyelerinin sinerjik etkisiyle Koç Holding bünyesinde yer alan 11 işletmenin 118 yönetim kurulu üyesiyle etkileşimli bir yönetim kurulu üyeliği bulunmaktadır. Ayrıca Yaşar Holding bünyesinde Altınyunus yönetim kurulunda yer alması neticesiyle 7 yönetim kurulu üyesiyle ilişkisi bulunurken yönetim kurulunda yer alan diğer yönetim kurulu üyelerinin sinerjik etkisiyle Yaşar Holding bünyesinde yer alan 6 işletmenin 42 yönetim kurulu üyesiyle holdingler arasında da bir ilişkisi bulunmaktadır.

Üçüncü sırada göze çarpan isim Mehmet Kahya'dır. Mehmet Kahya'nın özellikle finans, pazarlama ve otomotiv sektörü üzerine geniş deneyimleri bulunmaktadır. Örneklemde yer alan şirketler düzeyinde incelendiğinde Yaşar Holding bünyesinde DYO BOYA ve Viking Kağıt işletmelerinde, Sabancı Holding bünyesinde ise Çimsa ve Yünsan işletmelerinde dişardan bağımsız üye olarak yönetim kurullarında görev yaptığı görülmektedir. Yaşar Holding bünyesinde yer alan DYO Boya'da 7, Viking'te 7 yönetim kurulu üyesiyle aynı yönetim kurulunda yer aldıklarından dolayı bir ilişkisi bulunurken yönetim kurulunda yer alan diğer yönetim kurulu üyelerinin etkisiyle Yaşar Holding bünyesinde yer alan 6 işletmenin 42 yönetim kurulu üyeleriyle sinerjik bir ilişkisi bulunmaktadır. Sabancı Holding bünyesinde yer alan Çimsa'da 6, Yünsan'da 6 yönetim kurulu üyesiyle aynı yönetim kurulunda yer aldıklarından dolayı bir ilişkisi bulunurken yönetim kurulunda yer alan diğer yönetim kurulu üyelerinin etkisiyle Sabancı Holding bünyesinde yer alan 8 işletmenin 66 yönetim kurulu üyeleriyle sinerjik bir ilişkisi bulunmaktadır. Ayrıca Mehmet Kahya'nın yönetim kurulu üyesi olduğu işletme grupları kendi arasında sinerjik bir ilişkisiyle ortak yönetim kurulu üyeliklerini 
sürdürürken işletme grubu dışında da ortak yönetim kurulu üyelerine yer vermesi neticesinde108 yönetim kurulu üyesiyle Holdingler arasında da bir ilişkisi bulunmaktadır.

Dördüncü sırada göze çarpan isim Mustafa Vehbi Koç’tur. Mustafa Vehbi Koç Koç Holding'in yönetim kurullarında yer alan aile üyelerinden biridir. Örneklemde yer alan şirketler düzeyinde incelendiğinde Koç Holding bünyesinde Arçelik, Tat Gıda, Tofaş, Tüpraş, Yapı Kredi Bankası işletmelerinde, iç aile üyesi olarak yönetim kurullarında görev yaptığı görülmektedir. Koç Holding bünyesinde yer alan Arçelik'te 12, Tat Gıda'da 10, Tofaş'ta 12, Tüpraş'ta 15, Yapı ve Kredi bankasında 12 yönetim kurulu üyesiyle doğrudan bir ilişkisi bulunmaktadır. Yönetim kurulunda yer alan diğer yönetim kurulu üyelerinin etkisiyle Koç Holding bünyesinde yer alan 11 işletmenin 118 yönetim kurulu üyeleriyle sinerjik bir yönetim kurulu üyeliği ilişkisi bulunmaktadır. Mustafa Vehbi Koç’un Koç Holding dışında diğer işletmelerin yönetim kurulu üyeleriyle doğrudan bir ortak yönetim kurulu ilişkisi bulunmazken Koç Holding bünyesindeki işletmelerde yer alan yönetim kurulu üyelerinin diğer holdinglerde yer alan işletmelerle ortak yönetim kurulu üyeliğine gitmeleri neticesinde ortak yönetim kurulu üyeliği yapılan işletmelerin yönetim kurulu üyeleriyle de dolaylı yoldan ilişkili olduğu söylenebilmektedir.

Beşinci sırada göze çarpan isim Yahya Üzdiyendir. Yahya Üzdiyen Doğan Holding'in çeşitli işletmelerinin yönetim kurullarında yer alan iç üyelerden biridir. Örneklemde yer alan şirketler düzeyinde incelendiğinde Doğan Holding bünyesinde Hürriyet Gazetecilik, Doğan Burda Dergi Yayınc1lık, Doğan Şirketler Grubu Holding, Çelik Halat, Ditaş ve Doğan Gazetecilik işletmelerinde, iç üye olarak yönetim kurullarında görev yaptığı görülmektedir. 


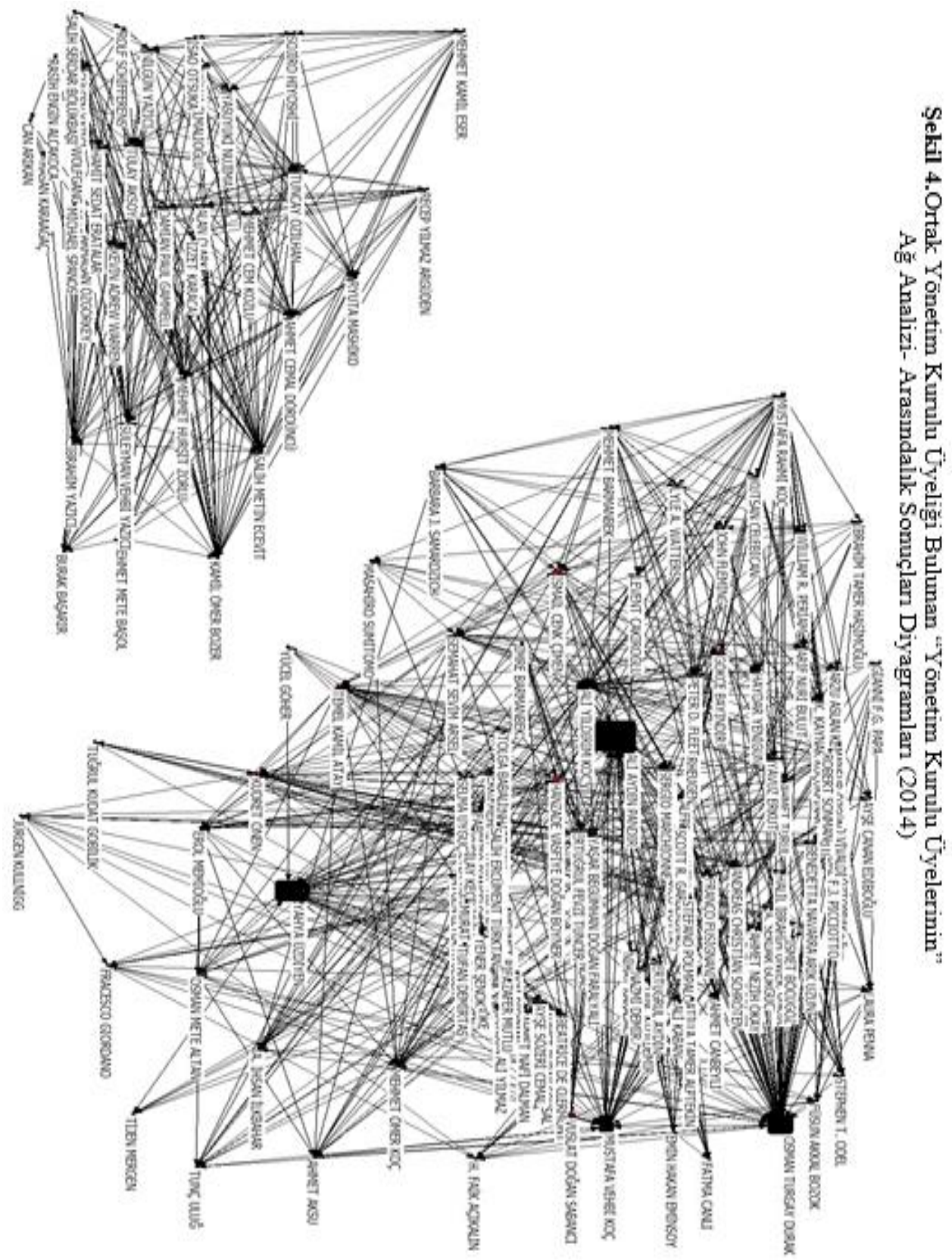

\section{SONUÇ VE TARTIŞMA}

$\mathrm{Bu}$ çalışmanın sonucunda elde edilen temel bulgular bütünsel olarak değerlendirildiğinde, ortak yönetim kurulu üyeliklerinin gelişmiş ülkeler ile gelişmekte olan ülkelerde faklı amaçlar doğrultusunda farklı yönetim kurulu üyelikleriyle oluşturulduğuna ve sadece ülke bağlamında değil Türkiye bağlamında 
da firmaları özelliklerine göre farklı düzeylerde ve farklı yönlerde etkilediğine işaret etmektedir. Örneklemde yer alan Eczacıbaşı İşletme Grubunun sadece kendisine bağlı işletmeler aracılığıyla oluşturulan ortak yönetim kurulu üyelikleri bulunmaktadır. Doğan İşletme Grubu'nun hem kendisine bağlı olan hem de kendisine bağlı olmayan işletmeler aracılığıyla oluşturulan ortak yönetim kurulu üyelikleri bulunmaktadır. Oyak İşletme Grubu'nun ise 2011 yılında sadece kendisine bağl işletmeler aracılığıyla oluşturulan ortak yönetim kurulu üyelikleri bulunurken 2014 yılında kendisine bağlı olmayan işletmeler aracılığıyla oluşturulan ortak yönetim kurulu üyeliklerinin de bulunması ortak yönetim kurulu üyeliklerinin aynı ülke bağlamında bile firma özelliklerine göre farklı şekillerde oluşturulduğunu destekler niteliktedir.

Ortak yönetim kurulu üyelikleri, gelişmiş ülkelerde bilgi paylaşımı ve belirsizlikle başa çıkma amacı ile oluşturulurken (Maman, 1999; Gulati ve Westphal, 1999) Türkiye'de ise sahipliği ellerinde bulunduran aileler tarafindan işletme grubunun bağlı şirketlerini denetlemek ve bu şirketler arasında koordinasyonu sağlamak için kullanılmaktadır (Ataay, 2008). Aile üyesi olarak yönetim kurulunda görev yapan İdil Yiğitbaşı'nın Yaşar İşletme Grubu bünyesinde gruba dâhil edilen 6 işletmenin 6'sında da yönetim kurulu üyeliği bulunmaktadır. İcracı üye olarak yönetim kurulunda görev yapan Yahya Üzdiyen' in Doğan İşletme Grubu bünyesinde gruba dâhil edilen 7 işletmenin 6'sında yönetim kurulu üyeliği bulunmaktadır. Aile üyesi olarak yönetim kurulunda görev yapan Olgun Zorlu'nun Zorlu İşletme Grubu bünyesinde gruba dâhil edilen 3 işletmenin 3'ünde de yönetim kurulu üyeliği bulunmaktadır. Örneklemde yer alan işletme gruplarının aynı yönetim kurulu üyelerini bağl1 şirketlerinin yönetim kurullarına yerleştirmesi ve bu yerleștirilen yönetim kurulu üyelerini ya aile üyelerinden ya da uzun yıllar işletmede çalişarak aileden biri gibi görülen yönetim kurulu üyelerinden seçmesi Ataay (2008) sonuçlarını destekler niteliktedir.

Doğrudan ortak yönetim kurulu üyelikleri, işletme grubunun bağl1 şirketlerini kontrol etmesini mümkün kılarken, dolaylı ortak yönetim kurulu üyelikleri ise bağlı şirketler arasındaki koordinasyonu sağlamak için oluşturulmaktadır (Mizruchi, 1996). Yıllar itibariyle doğrudan ve dolaylı ortak yönetim kurulu üyeliklerindeki değişime bakıldığında 2011 yılında \% 12 doğrudan $\% 12.5$ dolaylı, 2014 y1lında \% 15 doğrudan \% 13 dolaylı ortak yönetim kurulu üyeliği gerçekleştirildiği tespit edilmiştir. Doğrudan ortak yönetim kurulu üyeliklerinin dolaylı ortak yönetim kurulu üyeliklerine kıyasla azda olsa daha fazla arttığ1, tüm ortak yönetim kurulu üyeliklerinin ise 2011 yılına oranla daha fazla görüldüğü sonucuna ulaşılmıştır.

KAYNAKÇA

Amsden, Alice H., Hikino, T. (1994). Project Execution Capability, Organizational KnowveHow, and Conglomerate Corporate Growth in Late Industrialization. Industrial and Corporate, 3 (1), $111-148$.

Arıkboğa, Ş., Menteş, A. (2012). Türkiye'de Kurumsal Yönetişim İklimi. İktisat Fakültesi Mecmuası, 59 (2), 85-120. 
Ataay, A. (2008). Aile İşletme Gruplarında Karşı1lıklı Kenetlenmiş Yönetim Kurulları: İMKB 100 Şirketlerinden Bulgular. Tamer Koçel (Ed.), 3. Aile islemeleri Kongre Kitabı içinde (s. 1931). İstanbul: İstanbul Kültür Üniversitesi Yayınları.

Barringer, Bruce R., Harrison, Jeffery S. (2000). Walking a Tightrope: Creating Value Through Interorganizational Relationship. Journal of Management, 26 (3), 367-403.

Baycan, N. Ç., Semerciöz, F. (2013). Kaynak Bağımlılı̆̆ Yaklaşımı Temelinde, İMKB-100 Endeksindeki Şirketlerde Varolan Ortak Yönetim Kurulu Üyeliklerine Bir Bakış. Kemal Demirci ve diğerleri (Ed.), 21. Ulusal Yönetim ve Organizasyon Kongresi Bildiriler Kitabl içinde (s. 565-575). Ankara: Nobel Akademik Yayıncılık Eğitim Danışmanlık Tic. Ltd. Şti.

Buğra, A., Üsdiken, B. (1995). Societal Variations in State-Dependent Organizational Forms: The South Korean Chaebol and Turkish Holding Company. Emot (European Management and Organization in Transition) Workshop, Helsinki: Finland.

Buğra, A. (1995). Devlet ve Işsadamları. İstanbul: İletişim Yayınları.

Buğra, A. (2007). Devlet ve İşadamları. (5. Baskı). İstanbul: İletişim Yayınları.

Buğra, A. (2013). Devlet ve İşadamları. Fikret Adaman (Çev.). (8. Baskı). New York: State University of New York Press.

Borgatti, S., et al. (2002). Ucinet for Windows: Software for Social Network Analysis , Harvard. MA: Analytic Technologies.

Claessens, S., Simeon D. (1998). Managers, Incentives, and Corporate Performance: Evidence from the Czech Republic. Working Paper, World Bank.

Collin, S. O. (1998). Why Are These Islands of Conscious Power Found in the Ocean of Ownership? Institutional and Governance Hypotheses Explaining the Existence of Business Groups in Sweden. Journal of Management Studies, 35 (6), 719-746.

Çolpan, A. M., Hikino, T. (2008). Türkiye'nin Büyük Şirketler Kesiminde İşletme Gruplarının İktisadi Rolü ve Çeşitlendirme Stratejileri. Yönetim Araştırmaları Dergisi, Cilt 8, Sayı 1-2, 23-58.

Çolpan, A. M., Hikino, T. (2010). Foundations of Business Groups: Toward an Integrated Framework. Çlopan, Aslı M. ve diğerleri (Ed.), The Oxford Handbook of Business Groups içinde (s. 15-66). Oxford: Oxford University Press.

Demirağ, İ., Serter, M. (2003). Ownership Patterns and Control in Turkish Listed Companies. Corporate Governance, 11 (1), 40-51.

Dirlik, S. (2014a). Türkiye'de Egemen İktisadi Aktörler olarak İşletme Grupları. Finans Politik ve $\begin{array}{llll}\text { Ekonomik } \quad \text { Yorumlar, } & 51 & \text { 9-36. }\end{array}$ http://www.ekonomikyorumlar.com.tr/dergiler/makaleler/594/sayi_594_makale-01.pdf (25.05.2016).

Guillén, M. F. (2000). Business Groups in Emerging Economies: A ResourceveBased View. Academy of Management Journal, 43 (3), 362-380.

Gulati, R., Wetphal, J. D. (1999). Cooperative or Controlling? The Effects of CEO-Board Relations and the Content of Interlocks on the Formation of Joint Ventures. Administrative Science Quarterly, 44 (3), 473-506.

Granovetter, M. S. (2005). The Impact of Social Structure on Economic Outcomes. Journal of Economic Perspectives, 19 (1), 33-50.

İlhan, T. (2005). Uluslararası Ortak Girişimlerde Şirket İçi Tutarlı1ık ve Yerel Eşbiçimlilik Baskılarını Yönetmede Farklılaşan Stratejik İnsan Kaynakları Uygulamalarının Rolü. Yönetim Araştırmaları Dergisi, 5 (2), 81-119.

İlhan-Nas, T., Okan, T., Tatoğlu, E., Demirbağ, M. \& Glaister, K.W. (2018). The Effects of Ownership Concentration and Institutional Distance on the Foreign Entry Ownership Strategy of Turkish MNEs. Journal of Business Research, 93, 173-183.

İlhan-Nas T., Kalaycioğlu O. (2016). The Effects of the Board Composition, Board Size and CEO Duality on Export Performance: Evidence from Turkey. Management Research Review, 39, 1374-1409.

İlhan-Nas T., Çarkcı A. (2015). Yönetim Güçlendirmenin Firmanın Finansal Performansı ve Risk Alma Davranışı Üzerindeki Etkisi. ODTÜ Gelişim Dergisi, 42, 355-409. 
Karaevli, A. (2008). Türkiye'deki İşletme Gruplarında Çeşitlendirme Stratejilerinin Evrimi. Yönetim Araştırmaları Dergisi, 8 (1-2), 85-107.

Khanna, T., Rivkin, J. W. (2001). Estimating the Performance Effects of Business Groups in Emerging Markets. Strategic Management Journal, 22 (1), 45-74.

KHU-KPMG-T-DEIK-VCC (Kadir Has University, KPMG Turkey, the Foreign Economic Relations Board, Vale Columbia Center on Sustainable International Investment). (2011). Turkish Multinationals Steady On Their Course Despite Crisis, Survey Finds. http://sites.khas.edu.tr/EMGP/report.html, Date of Access: 11.11.2018.

Koca, M. A. (2015). İşletme Gruplarında Çeşitlenme ve Bilgi Alanı Yönetimi: Türkiye Örneği. (Yayımlanmamış Doktora Tezi). Başkent Üniversitesi / Sosyal Bilimler Enstitüsü, Ankara.

Koçer, B. (2006). İ̧sel Bir Yönetişim Mekanizması Olarak Yönetim Kurulları: IMKB'de Işlem Gören Şirketlerin Yönetim Kurulu Yapısı ve İşlevleri Üzerine Bir Araştırma. (Yayımlanmamış Doktora Tezi). İstanbul Üniversitesi / Sosyal Bilimler Enstitüsü, İstanbul.

Maman, D. (1999). Research Note: Interlocking Ties within Business Groups in Israel - A Longitudinal Analysis, 1974-1987. Organization Studies, 20 (2), 323-339.

Maman, D. (2002) The Emergence of Business Groups in Israel and South Korea Compared. Organization Studies, 23 (5), 737-758.

Mizruchi, M. S. (1996). What do interlocks do? An analysis, Critique, and Assessment of Research on Interlocking Directorates. Annual Review of Sociology, 22, 271-298.

Özkara, B., ve diğerleri. (2008). Türkiye'de İşletme Grupları: Eskiler ve Yeniler. Yönetim Araștırmaları Dergisi, 8 (1-2), 59-83.

Scott, J. (2000). Social Network Analysis: a Handbook. (2. Bask1). London: Sage Publications.

Selekler-Gökşen, N., Üsdiken, B. (2001). Uniformity and Diversity in Turkish Business Groups: Effects of Scale and Time of Founding. Brisith Journal of Management, 12, 325-340.

Selekler-Gökşen, N., Karataş, A. (2008). Board Structure and Performance in an Emerging Economy: Turkey. International Journal of Business Governance and Ethics, 4 (2), 132-147.

Shleifer, A., Vishny, R. W. (1997). A Survey of Corporate Governance. Journal of Finance, 52 (2), 737-783.

Şenalp, G. M., Öztürk, Ö. (2014). Interlocking Directorates and Capitalist Class Formations in Turkey: A Study on the Listed Firms in Istanbul Stock Exchange and Istanbul Chamber of Industry (ISO 500). World Congress of Sociology, 13-19 July. Japan: Yokohama.

Üsdiken, B., Öktem, Ö. Y. (2008). Kurumsal Ortamda Değişim ve Büyük Aile Holdingleri Bünyesindeki Şirketlerin Yönetim Kurullarında "İcrada Görevli Olmayan" ve "Bağımsız" Üyeler. Amme İdaresi Dergisi, 41 (1), 43-71.

Yurtoğlu, B. B. (2003). Corporate Governance and Implications for Minority Shareholders in Turkey. Journal of Corporate Ownership and Control, 1 (1), 72-86.

https://www.osha.gov/pls/imis/sic_manual.html

http://www.iso500.org.tr/

www.kap.gov.tr Erişim Tarihi: 28.07.2016.

\section{SUMMARY}

In this study, it is aimed to examine the current network structures of shared board memberships which are common in Turkish business groups in the context of corporate governance. Two research questions put forward in this direction guide the study. The first of these questions is related to who the members of the joint board of directors of Turkish family business groups are. When the year 2012, when the new Turkish Commercial Code came into force, is taken as the breaking point, whether there has been any change in the profile of the joint board member before and after this year comes up as the second important research question that forms the basis of the study. 
In this context, the network structures of the joint board memberships of the 10 business groups determined by the judgemental sampling method are presented by utilizing the secondary data obtained from 2011 and 2014. While determining the universe of the study, "Turkey's 50 largest economic actors" list which is in the study conducted by Çolpan and Hikino (2008) and "The top 19 Turkish non-financial multinationals" list in the study published by KHU-KPMGT-DEIK-VCC (2011) are referenced. When all firms in these two studies combined, 63 business groups operating in Turkey are obtained. Within the framework of intentional sampling method, the sample of the study consists of 61 affiliated institutions which operate in at least 3 different sectors, at least three of its subsidiaries are publicly traded, and at least one of its affiliates is one of the 10 holding companies listed in the ISO 5002014 company rankings. UCINET program was used for social network analysis in order to reveal common board networks and member profiles in Turkish business groups. After determining which holdings which companies, which board members and which enterprises hold joint work with the board members for the holdings included in the sample, the weighted obtained data were transferred to frequency tables created under the UCINET program. NETDRAW and UCINET programs are shown graphically in order to see the relations between the nodes formed within the obtained social network in more detail. At this stage, the profile of the business groups and the members of the board of directors working in these enterprises were compared and the role of the members of the board of directors of the business groups and the centrality and interrelationships of these members were revealed by looking at the centrality and betweenness data of the companies included in the sample in 20112014. In the social network analysis process applied within the scope of the study, two different perspectives were adopted at the firm and individual level while obtaining the network structures of the members of the joint board of directors. In this context; at the firm level, the social network matrix, defined at the level of "business groups and affiliates" having joint board members, represents the social network between firms that have joint board members among themselves. At the individual level, the network matrix defined at the level of "board members" with common board members represents the social network between individuals who work together on the boards of different firms.

Considering all the networks, the most central actors with joint board members in Turkish business groups are either family members or internal members who are now seen as one of the family members after many years of working in the company, yet in the automotive sector, it is seen that these members are composed of company CEOs with extensive experience in the sector. When the main findings obtained as a result of this study are evaluated holistically, it indicates that joint board memberships are formed with different board memberships for different purposes in developed and developing countries and not only in the country but also in the context of different levels according to the characteristics that affect the company in the context of Turkey and in different directions. Looking at the changes in the direct and indirect joint board 
memberships by years, it was found that $12 \%$ direct $12.5 \%$ indirect in $2011,15 \%$ direct and 13\% indirect in 2014 joint board membership was realized. It has been concluded that direct joint board memberships have increased slightly more than indirect joint board memberships and that all joint board memberships have been seen more than in 2011. 